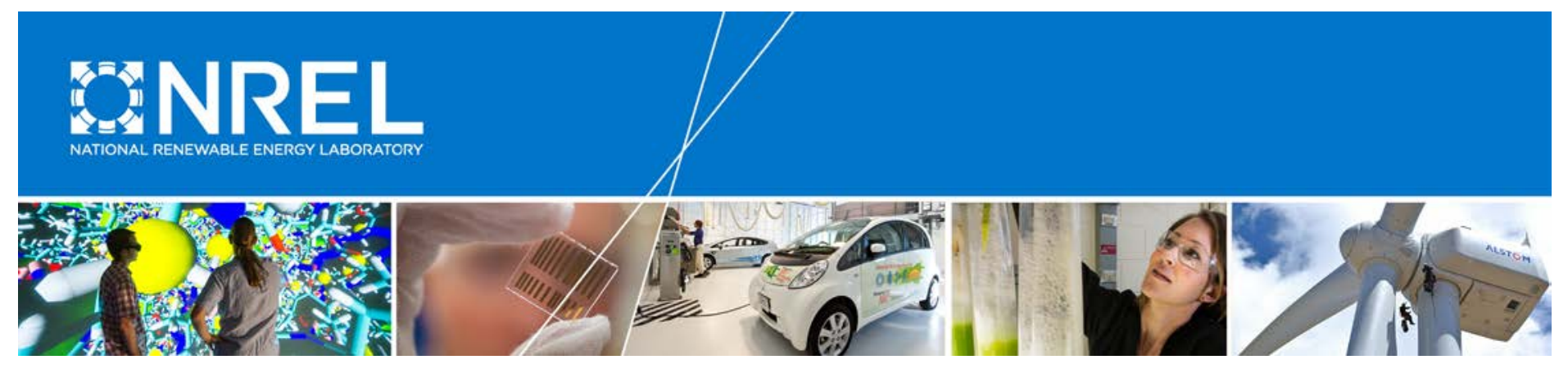

\title{
Impact of Rate Design Alternatives on Residential Solar Customer Bills: Increased Fixed Charges, Minimum Bills and Demand-Based Rates
}

Lori Bird, Carolyn Davidson, Joyce McLaren, and John Miller

National Renewable Energy Laboratory

NREL is a national laboratory of the U.S. Department of Energy Office of Energy Efficiency \& Renewable Energy Operated by the Alliance for Sustainable Energy, LLC

This report is available at no cost from the National Renewable Energy Laboratory (NREL) at www.nrel.gov/publications.

Technical Report

NREL/TP-6A20-64850

September 2015 


\section{Impact of Rate Design Alternatives on Residential Solar Customer Bills: Increased Fixed Charges, Minimum Bills and Demand- Based Rates}

Lori Bird, Carolyn Davidson, Joyce McLaren, and John Miller

National Renewable Energy Laboratory

Prepared under Task No. SM13.1560

NREL is a national laboratory of the U.S. Department of Energy Office of Energy Efficiency \& Renewable Energy Operated by the Alliance for Sustainable Energy, LLC

This report is available at no cost from the National Renewable Energy Laboratory (NREL) at www.nrel.gov/publications.

National Renewable Energy Laboratory 15013 Denver West Parkway Golden, CO 80401

303-275-3000 • www.nrel.gov

\section{Technical Report}

NREL/TP-6A20-64850

September 2015

Contract No. DE-AC36-08GO28308 


\title{
NOTICE
}

This report was prepared as an account of work sponsored by an agency of the United States government. Neither the United States government nor any agency thereof, nor any of their employees, makes any warranty, express or implied, or assumes any legal liability or responsibility for the accuracy, completeness, or usefulness of any information, apparatus, product, or process disclosed, or represents that its use would not infringe privately owned rights. Reference herein to any specific commercial product, process, or service by trade name, trademark, manufacturer, or otherwise does not necessarily constitute or imply its endorsement, recommendation, or favoring by the United States government or any agency thereof. The views and opinions of authors expressed herein do not necessarily state or reflect those of the United States government or any agency thereof.

This report is available at no cost from the National Renewable Energy Laboratory (NREL) at www.nrel.gov/publications.

Available electronically at SciTech Connect http:/www.osti.gov/scitech

Available for a processing fee to U.S. Department of Energy and its contractors, in paper, from:

\author{
U.S. Department of Energy \\ Office of Scientific and Technical Information \\ P.O. Box 62 \\ Oak Ridge, TN 37831-0062 \\ OSTI http://www.osti.gov \\ Phone: 865.576.8401 \\ Fax: 865.576.5728 \\ Email: reports@osti.gov
}

Available for sale to the public, in paper, from:

\author{
U.S. Department of Commerce \\ National Technical Information Service \\ 5301 Shawnee Road \\ Alexandria, VA 22312 \\ NTIS http://www.ntis.gov \\ Phone: 800.553 .6847 or 703.605 .6000 \\ Fax: 703.605.6900 \\ Email: orders@ntis.gov
}




\section{Acknowledgments}

This report presents data and modeling results to examine impacts of rate design alternatives on customer electricity bills. A complementary report, Compensation for Distributed Solar: A Survey of Options to Preserve Stakeholder Value, provides a framework of mechanisms that address compensation for PV owners, alternative retail rate design, and utility value preservation. Together, these NREL reports address some of the issues at the intersection of utility policy and compensation mechanisms for distributed generation customers.

The authors thank the Department of Energy's SunShot Initiative for its support of this work. For their consultation, the authors would like to thank Tom Stanton, National Regulatory Research Institute; Galen Barbose and Naim Darghouth, Lawrence Berkeley National Laboratory; Karlynn Cory, Janine Freeman, David Hurlbut, Emerson Reiter, Jeff Logan, Robin Newmark, Mary Werner and Gian Porro, National Renewable Energy Laboratory.

We would also like to thank Leland Snooks (Arizona Public Service), Jeff Bailey (Duke Energy), Beth Chacon and Donald Garretson (Xcel Energy), Tom Stanton (National Regulatory Research Institute), Joseph Wiedman (Keyes, Fox and Wiedman LLP), and Jim Lazar and Carl Linvill (Regulatory Assistance Project) for their invaluable perspectives and reviews along the way. Individual members may have different views on one or more matters addressed in the report. They were not asked individually or collectively to endorse the report findings nor should any implied endorsement by the sponsoring organizations be assumed. All authors contributed equally to this report. 


\section{List of Acronyms}

$\begin{array}{ll}\text { AMI } & \text { advanced metering infrastructure } \\ \text { APS } & \text { Arizona Public Service } \\ \text { CPUC } & \text { California Public Utilities Commission } \\ \text { DG } & \text { distributed generation } \\ \text { Duke } & \text { Duke Energy Carolinas } \\ \text { EIA } & \text { U.S. Energy Information Administration } \\ \text { FP\&L } & \text { Florida Power \& Light } \\ \text { GTM } & \text { Greentech Media } \\ \text { IOU } & \text { investor-owned utility } \\ \text { JCP\&L } & \text { Jersey Central Power \& Light } \\ \text { kW } & \text { kilowatt } \\ \text { kWh } & \text { kilowatt-hour } \\ \text { LADWP } & \text { Los Angeles Department of Water and Power } \\ \text { NEM } & \text { net energy metering } \\ \text { NPCo } & \text { Nevada Power Company } \\ \text { NSPCo } & \text { Northern States Power Company } \\ \text { NSTAR } & \text { NSTAR Gas and Electric } \\ \text { PG\&E } & \text { Pacific Gas and Electric Company } \\ \text { PGECo } & \text { Portland General Electric Company } \\ \text { PSCo } & \text { Public Service Company of Colorado } \\ \text { PV } & \text { photovoltaic } \\ \text { SAM } & \text { System Advisor Model } \\ \text { TMY3 } & \text { Typical Meteorological Year } 3 \\ \text { TOU } & \text { time-of-use } \\ \text { VEPCo } & \text { Virginia Electric and Power Company } \\ & \end{array}$




\section{Executive Summary}

With rapid growth in energy efficiency and distributed generation, electric utilities are anticipating stagnant or decreasing electricity sales, particularly in the residential sector. Utilities are increasingly considering alternative rates structures that are designed to recover fixed costs from residential solar photovoltaic (PV) customers with low net electricity consumption. Proposed structures have included fixed charge increases, minimum bills, and increasingly, demand rates - for net metered customers and all customers.

This study examines the electricity bill implications of various residential rate alternatives for multiple locations within the United States. First, we model the interaction of customer demand, PV generation and grid exports in several utilities. In addition, we estimate the portion of a customer's electricity demand that is offset with on-site residential PV in states where data is available. Second, we analyze the implications of various alternative rate structures on residential consumer bills, for PV and non-PV customers for a set of six utilities with existing demandbased residential rates. Rate alternatives evaluated include increased fixed charges and minimum bills of $\$ 10$ and $\$ 50$, as well as demand-based rates. Energy charges were not reduced for fixed charges and minimum bills in this analysis (as they would be in typical rate case) because of the many utility-specific factors and complex interactions that would have to be accounted for to maintain utility revenue. Demand-based rates are pulled from utilities with existing, opt-in residential demand rates.

In the states evaluated, systems typically offset from just under two-thirds to nearly all of a particular household's load. However, roughly $65 \%$ of a typical customer's electricity demand is non-coincidental with PV generation, so the typical PV customer is generally highly reliant on the grid for pooling services.

Results of the rate analysis included the following:

- Increasing the fixed charge by $\$ 50$ without any reduction in energy charge resulted in the most substantial increase in the annual electricity bill, in all regions.

- The other rate options are more closely aligned, in most of the utility service areas examined. Instituting a $\$ 10$ minimum bill increased costs the least, as most customers continued to pay the minimum even with PV.

- Demand charges resulted in an increase in utility bills of $35 \%$ or higher for PV customers in three of the five utilities evaluated. In the remaining three utilities, changes were minimal. The impact of demand-based rates on customer bills critically depended on the rate design, load profile and coincidence of PV production with load.

Demand-based rates varied significantly in terms of the charge components (demand charge, fixed charge, and reduction in energy charge) as well as the rate design (demand interval and temporal structure). Results suggest the importance of collecting data on customer load, PV generation, sizing and timing in order to precisely evaluate impacts of rate changes on various customer types. 


\section{Table of Contents}

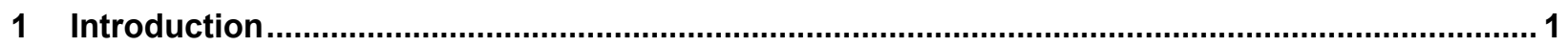

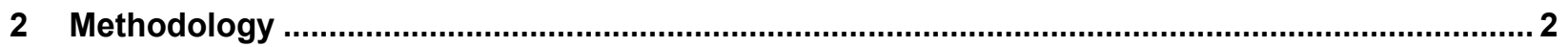

3 Understanding Residential PV Customer Grid Consumption and Export Patterns ..................... 4

3.1 Average Sizes of Installed Residential PV Systems................................................................ 4

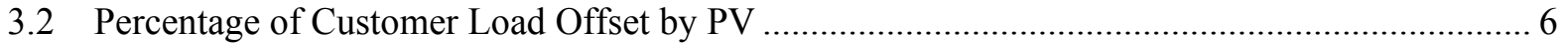

3.3 Coincidence of PV Generation with Customer Load .............................................................. 7

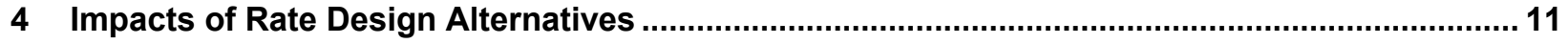

4.1 Analysis of Rate Design Impacts ............................................................................... 11

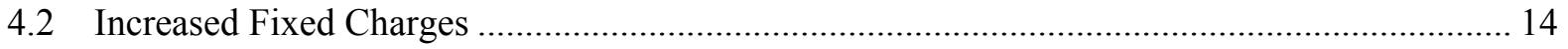

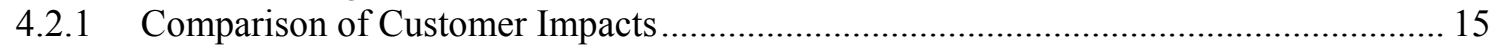

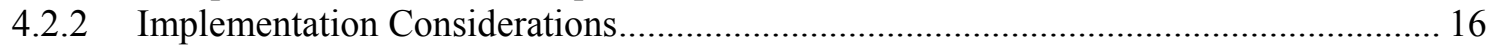

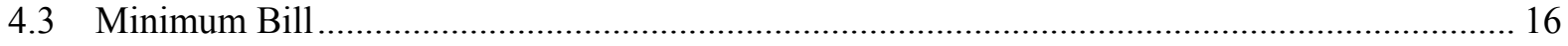

4.3.1 Comparison of minimum bills with increasing fixed charges................................... 16

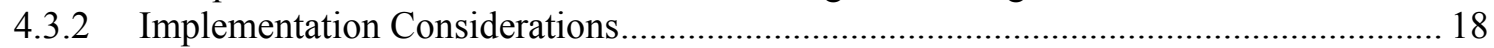

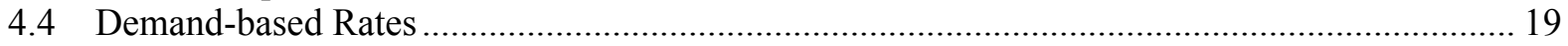

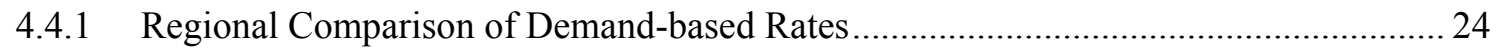

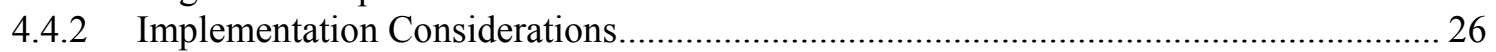

4.5 Comparison Across Rate Alternatives ...................................................................... 28

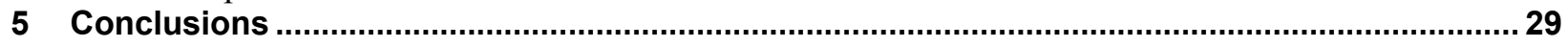

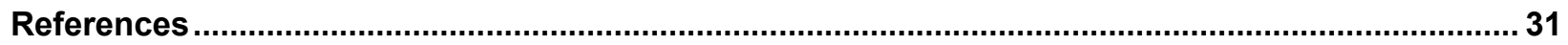

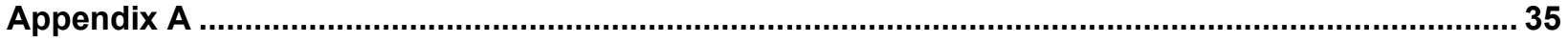

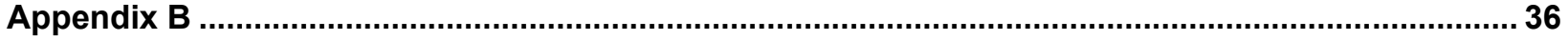

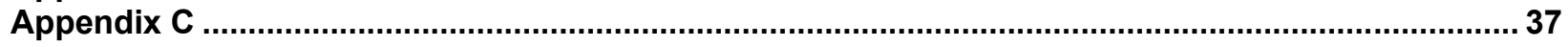




\section{Introduction}

With rapid growth in energy efficiency and distributed generation (e.g., solar photovoltaics $[\mathrm{PV}])$, many electric utilities are facing or anticipating stagnant electricity sales, particularly in the residential sector (Bird et al. 2013; Raskin 2013). This reduction in billable energy raises concerns about the utility's ability to recover fixed costs, which comprise the majority of their expenses (Kind 2013). At the same time, the vast majority of the distributed solar installations remain connected to the grid, and system owners rely on the grid for multiple functions, including voltage and frequency control, managing imbalances between system generation and system demand and the opportunity to receive economic benefit from exporting excess generation (Raskin 2013). In response, increasing numbers of utilities are proposing changes to residential rate structures with the goal of recovering fix costs from customers with gridconnected distributed generation.

The most commonly proposed rate adjustments have been increased fixed charges, minimum bills and residential demand-based rates. Demand charges have been implemented by some utilities on an opt-in basis for residential customers (Hledik 2014). Several other utilities have proposed increased fixed charges for all residential customers, or in some cases only distributed generation customers. Minimum monthly bills, which ensure that all grid-connected customers pay a specified minimum amount each month, despite the amount of electricity they purchase from the utility, have been suggested but not yet implemented at the residential level.

Several studies have explored the impacts of commercial electric utility rate structures on PV system economics (Ong et al. 2010, 2012, 2013; Darghouth et al. 2014). These indicate that PV adoption is highly sensitive to rate structures, and that time-varying rates, higher fixed charges or changes to net metering could impact aggregate PV adoption. A large and growing body of literature has addressed evolving utility business models and/or options for utilities to maintain the revenue needed to cover fixed system costs (Costello 2015, Darghouth 2015; Bird et al. 2013, Kind 2013, Linvill et al. 2013; Newcomb 2013).

This paper builds on existing literature by examining the implications of several recently proposed residential rate types on residential customer utility bills for multiple locations within the United States. We begin by determining, for various regions, the portion of a customer's electricity load that is typically offset with an on-site residential PV systems. The percentage of load that is offset by distributed generation is of interest because, under traditional rate structures, the degree to which distributed PV systems reduce the purchase of electricity from the utility directly impacts utility revenue recovery. Second, we analyze the implications of various alternative rate structures on residential consumer bills, for PV and non-PV customers, including increased fixed charges, minimum bills, and demand-based rates. 


\section{Methodology}

The first step in the analysis was to determine average PV system sizes for utilities in multiple locations. We calculated these (in $\mathrm{kW}$-DC) using 2013 residential net metering data provided by utilities to the U.S. Energy Information Administration (EIA 2015). The percentage of residential load that is off-set by PV system sizes for each state was then calculated using proprietary PV system quote information from Energy Sage. Energy Sage is an online bidding platform, through which potential customers request online quotes from PV system developers by providing information on their location, electricity usage, and other variables.

We then determined the coincidence of PV production with customer load by comparing PV production curves for the average system sizes with simulated residential load data. PV production data was generated using NREL's System Advisor Model (SAM), a technology performance and economic model designed to facilitate decision-making and analysis for renewable energy projects (Gilman and Dobos 2012). SAM uses the Typical Meteorological Year 3 (TMY3) dataset of the National Solar Radiation Database (Wilcox and Marion 2008) for a particular location along with user-defined inputs and assumptions about technology type and performance to simulate an hourly PV generation curve over the course of a year. Individual utilities were modeled, since SAM associates inputs such as climactic, geographic, and load data with specific electric rates in order to generate PV system outputs. The utilities were selected to represent the fastest growing PV markets while capturing geographic variability in solar resources and electricity consumption patterns.

Energy Plus Software was used to simulate load dataset profiles that represent hourly household consumption over one 'typical' year for various regions of the country. Energy Plus uses reference housing parameters and a nationally representative, base-case load profile, designed using the "Building America House Simulation Protocols" (Hendron et al. 2010). These simulated datasets allowed for the calculation of the net consumption of a self-generating household (e.g., the amount of electricity that is drawn from the utility grid) as well as the impact of various rate structures on customer bills. For this analysis, we assumed that households with and without PV systems have identical load profiles. ${ }^{1}$ Three load scenarios (low, base, and high) were modeled for each jurisdiction examined. The 'base case' assumes the 'base' residential electric load profile as applied within SAM, which was used to simulate data and analyze grid usage/exports by PV customers within specified utility territories. The resulting loads are presented in Table 1.

\footnotetext{
${ }^{1}$ We did not have sufficient data available to adjust load profiles for solar customers. This is of consequence only where comparisons are made between solar and non-solar customers.
} 
Table 1. Annual Modeled Residential Load: “Low”, "Base”, and "High” Loads

\begin{tabular}{|c|c|c|c|}
\hline LOCATION & $\begin{array}{c}\text { "LOW" } \\
\text { Annual Residential } \\
\text { Electricity Consumption } \\
\text { (kWh) }\end{array}$ & $\begin{array}{c}\text { "BASE CASE" } \\
\text { Annual Residential } \\
\text { Electricity Consumption } \\
\text { (kWh) }\end{array}$ & $\begin{array}{c}\text { "HIGH" } \\
\text { Annual Residential } \\
\text { Electricity Consumption } \\
\text { (kWh) }\end{array}$ \\
\hline Arizona-APS & 6,020 & 12,918 & 21,520 \\
\hline California-PG\&E & 3,908 & 7,563 & 10,177 \\
\hline Colorado-PSCo & 4,320 & 9,020 & 13,741 \\
\hline Florida-FPL & 7,587 & 14,690 & 25,299 \\
\hline Massachusetts-NSTAR & 4,382 & 9,011 & 13,836 \\
\hline Minnesota-NSPCo & 4,469 & 9,235 & 14,417 \\
\hline Nevada-SPPCo & 4,361 & 9,034 & 14,109 \\
\hline New Jersey-JCP\&L & 6,662 & 12,223 & 17,688 \\
\hline North Carolina-Duke & 6,962 & 12,880 & 19,280 \\
\hline Oregon-PGECo & 3,999 & 7,753 & 10,475 \\
\hline Texas-AustinEnergy & 7,129 & 14,796 & 26,964 \\
\hline AVERAGE & 5,436 & 10,829 & 17,046 \\
\hline
\end{tabular}

Source: OpenEl 2015. Notes: Pacific Gas \& Electric (PG\&E); Portland General Electric (PGECo); Pacific Service Company of Colorado (PSCo); Sierra Pacific Power Company (SPPCo); Northern States Power Company (NSPCo); Jersey Central Power and Light (JCP\&L); Florida Power and Light (FPL).

Lastly, we use SAM to investigate how changes in rate design impact both PV and non-PV customer bills, again for specific utilities. For this analysis, we focus on approximately half of the utilities that, at the time of this writing, have already implemented residential demand charges. $^{2}$ Rather than using average system sizes for each utility, we model a $5 \mathrm{~kW}$ system for all locations, in order to isolate the effects of the rate adjustments. Other SAM inputs included the simulated residential load data and the residential retail rate of interest. In each case, the standard retail rate was based on the utilities' spring 2015 rate sheets. Outputs included monthly PV generation, electricity consumption, electricity exports and electricity bill totals for each case. Electricity bills were then disaggregated into their energy, fixed and demand components, according to specific utility bill structures.

The rate designs evaluated using this method included each utility's existing standard rate, the standard rate with an increased fixed charge by $\$ 10$ and by $\$ 50$, a minimum bill of $\$ 10$ and of $\$ 50$, and each utility's existing demand charge. All adjustments and riders were included in the modeled rates. In practice, if fixed charges and minimum bills were applied to all customers (rather than only solar customers) energy charges would typically be decreased, in order to maintain revenue neutral rates for the utility. However, energy charges were not reduced for this analysis because of the many utility-specific factors and complex interactions that would have to be accounted for to appropriately adjust this charge for each utility. The appropriate adjustment depends on the current and projected percentage of customers subscribing as well as how changes will impact seasonal and tiered components of the energy rate. Thus, it is problematic to estimate the amount by which a energy charge would need to decrease to maintain revenue neutrality or to make a generalization across multiple utilities for this analysis.

\footnotetext{
${ }^{2}$ We selected utilities based on the following criteria: provide both geographic breadth and representation of utilities with active solar markets.
} 


\section{Understanding Residential PV Customer Grid Consumption and Export Patterns}

The amount of electricity that residential PV customers consume from the utility and export back to the grid, as well as the timing of these flows, has important impacts on utility system operations. This, in turn, has implications for rate design, customer bills and utility cost recovery. Use of grid pooling services depends both on system sizing and load coincidence. Numerous variables impact customer decisions regarding system sizing, including aesthetics, locational limitations, project economics, applicable utility rates, and policies or regulations (e.g., constraints on system sizing, net metering). For example, in locations where tiered rates exist, certain system sizes, relative to load, could cause customers to fall into the most expensive rate tier. In locations with flat rates and few net metering limitations, systems may be sized larger, relative to load.

The greater the coincidence of the solar generation with the customer's load, the fewer demands the customer places on the utility system to provide critical pooling services, providing generation when the PV system is not generating and accepting excess electricity when generation exceeds demand. Under high penetrations of distributed generation, greater coincidence of on-site generation and load could possibly delay the need for system up-grades, reduce the amount of necessary generating capacity reserves, or both. Lower coincidence of PV generation with on-site load increases the need for utilities to ramp their own generation resources up or down to balance system supply and demand on the grid.

In this section we present the results of the analyses on average system sizes, the percentage of customer load off-set by PV in different locations, the net demand of electricity from the grid, net exports of solar generation to the grid, and the coincidence of the PV generation and customer demand profile. The overall aim is to understand the extent to which PV customers in various locations rely on electricity purchased from the utility and the extent to which they rely on the grid.

\subsection{Average Sizes of Installed Residential PV Systems}

Based on EIA data, average residential PV system sizes in the utility service territories examined range between $3.92 \mathrm{~kW}$ and $8.78 \mathrm{~kW}$, with an average system size of $5.48 \mathrm{~kW}$. Figures were similar when calculated on a statewide basis (Table 2$){ }^{3}$

\footnotetext{
${ }^{3}$ The reported data included some systems above $20 \mathrm{~kW}$ in size. These were considered to be outliers and were excluded from the calculation of state average system sizes.
} 
Table 2. 2013 State and Utility Reported Average Residential PV System Size Comparison (kW)

\begin{tabular}{|c|c|c|c|}
\hline STATE & UTILITY AREA & $\begin{array}{l}\text { AVERAGE RESIDENTIAL } \\
\text { PV SYSTEM SIZE } \\
\text { (kW (DC)) FOR UTILITY }\end{array}$ & $\begin{array}{c}\text { AVERAGE RESIDENTIAL PV } \\
\text { SYSTEM SIZE } \\
\text { (kW (DC)) FOR STATE }^{\mathrm{b}}\end{array}$ \\
\hline ARIZONA & Arizona Public Service & 6.02 & 6.01 \\
\hline CALIFORNIA & Pacific Gas \& Electric & 4.87 & 4.53 \\
\hline COLORADO & Public Service Company of Colorado & 5.61 & 4.41 \\
\hline FLORIDA & Florida Power \& Light Company & 5.29 & 5.59 \\
\hline MASSACHUSETTS & NSTAR Electric Company & 5.88 & 6.03 \\
\hline MINNESOTA & Northern States Power Company & 5.88 & 6.18 \\
\hline NEVADA & Nevada Power Company & 5.78 & 5.38 \\
\hline NEW JERSEY & Jersey Central Power \& Light Company & 8.78 & 7.69 \\
\hline NORTH CAROLINA & Duke Energy Progress & 3.94 & 5.34 \\
\hline OREGON & Portland General Electric Company & 4.26 & 4.53 \\
\hline TEXAS & Austin Energy ${ }^{a}$ & 3.92 & 6.26 \\
\hline \multicolumn{2}{|l|}{ AVERAGE } & 5.48 & 5.63 \\
\hline \multicolumn{4}{|c|}{$\begin{array}{l}{ }^{3} \text { Austin Energy was chosen as it had the state's third largest amount of installed residential PV capacity, yet served a greater number of } \\
\text { PV customers relative to the two utilities with higher levels of installed residential PV capacity. }\end{array}$} \\
\hline \multicolumn{4}{|c|}{ bState average system sizes were calculated by excluding all calculated utility system sizes that were above $20 \mathrm{~kW}$. } \\
\hline
\end{tabular}

Source: U.S. Energy Information Administration (EIA) Form 861 (2015).

Figure 1 shows the distribution of PV system sizes nationwide, based on the OpenPV dataset. Nearly half of reported PV installations are between 3 and $6 \mathrm{~kW} .{ }^{4}$ The figure presents systems sized at $10 \mathrm{~kW}$ or less, which may include some small commercial systems.

\footnotetext{
${ }^{4}$ This data is derived from the OpenPV database https://openpv.nrel.gov/, a database on more than 420,000 U.S. PV installations provided by sources such as utilities, installers, and the general public. This distribution represents all systems equal to or less than $10 \mathrm{~kW}$, including residential and commercial systems.
} 


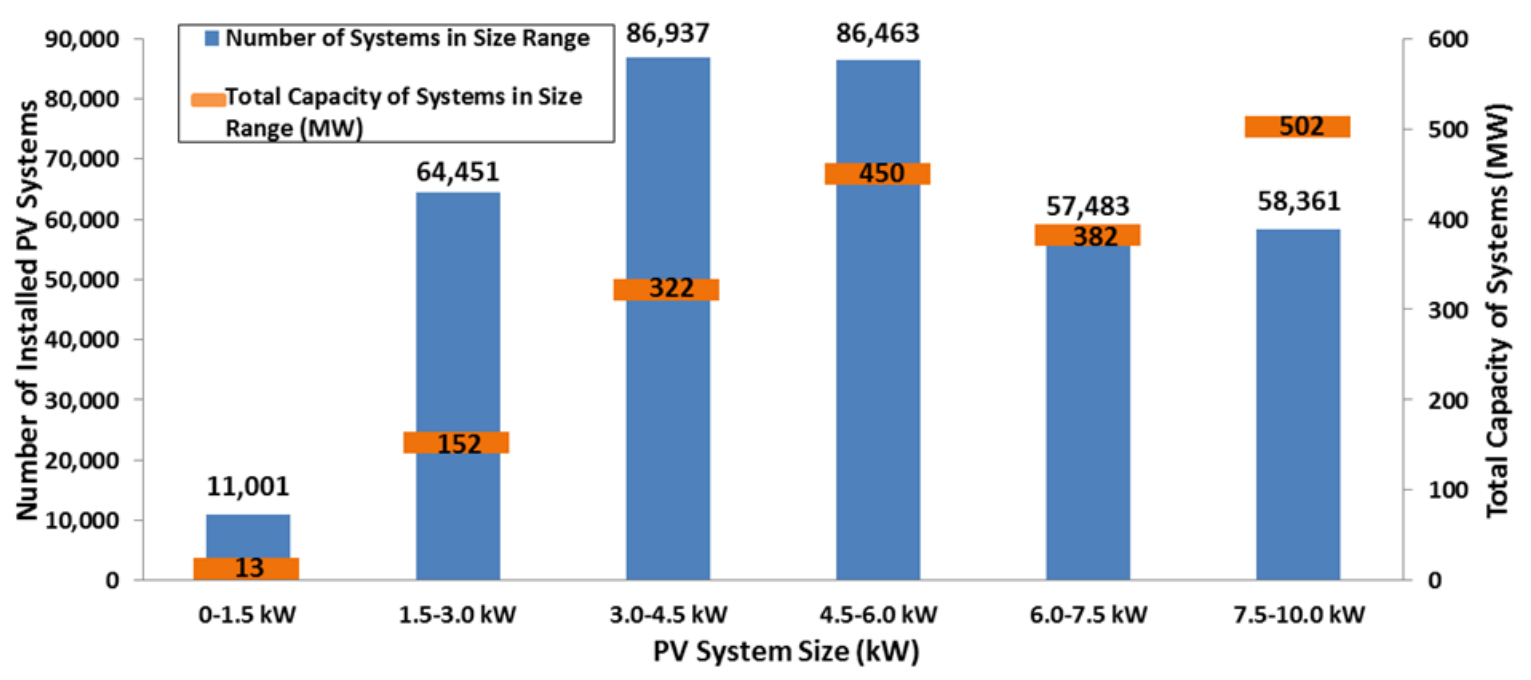

Figure 1. Number of Residential PV Systems Installed by Size

Source: OpenPV data, March 2015

\subsection{Percentage of Customer Load Offset by PV}

The load percentage that a PV system offsets impacts subsequent PV customer electric bills based on the applicable utility-specific rate structure(s) in place. For example, where utilities have tiered rates (such as in California), installers often propose system sizes that are intended to offset consumption in the most expensive tier. Alternatively, utility-specific net metering strongly influences the economics of system sizing; systems may be sized larger relative to load, where net metering rules have higher limits on exports. However, there is no spatially-broad public data available by utility to evaluate the relationship, so we rely on limited market data available by state.

The market data is derived from Energy Sage - an online solar quote platform. This confidential data provides a sample of data on proposed system size and previous year's electricity consumption for a sample of thousands of residential PV quotes; from this, the average state PV sizing ratio is calculated (Table 3 ) for states with more than 30 quotes. While this data does not indicate whether a quote was ultimately selected, it indicates the range of system sizes that are likely to be installed in a particular location, assuming installers follow economic sizing conventions based on their experience in a particular market. 
Table 3. Percentage of State Residential Load Offset Reported to Energy Sage

\begin{tabular}{|l|l|}
\hline State & Percent of load offset \\
\hline Arizona & $96 \%$ \\
\hline California & $96 \%$ \\
\hline Colorado & $99 \%$ \\
\hline Massachusetts & $90 \%$ \\
\hline New Jersey & $98 \%$ \\
\hline North Carolina & $61 \%$ \\
\hline Oregon & $70 \%$ \\
\hline Texas & $71 \%$ \\
\hline
\end{tabular}

Source: Energy Sage (2015). Note: Energy Sage data is reported by state, not utility service area.

Based on the Energy Sage data for the states evaluated, systems typically offset from just under two-thirds to nearly all of a particular household's load, with the highest off-set occurring in Colorado, California, and New Jersey and lowest in Texas and North Carolina. Note that energy demand is not static. These figures are based on electric bills in the year prior to receiving a quote and future electricity demand could increase or decrease based on energy efficiency improvement and changes in the demand patterns of household occupants.

\subsection{Coincidence of PV Generation with Customer Load}

The degree to which on-site solar generation coincides with load has important impacts on the operation of the electricity system. The more a solar self-generation profile aligns with a household's load profile, the less that household will depend on the distribution system to absorb excess solar generation and the less it will draw on utility generation when solar production is not meeting total power demand.

Under high penetrations of distributed generation, greater coincidence of on-site generation and load could possibly delay the need for system upgrades, reduce the amount of necessary generating capacity reserves, or both. Figure $2^{5}$ presents the modeled annual PV generation, household consumption, and export characteristics for average sized residential PV systems, by state, using "base case" scenario results simulated within SAM. Residential on-site PV generation plus grid consumption equals the overall annual household load. The annual grid exports are the sum of the excess PV generation that is not needed on-site at the time of production and is, thus, fed onto the grid. ${ }^{6}$ Together, the PV consumption plus the grid exports equal the total generation from the PV system over the course of the year. Under net metering,

\footnotetext{
5 Summing "On-site Residential PV Generation" and "Annual Grid Consumption" for each location equals the total residential electricity consumption in kilowatt-hours (kWhs).

"Base Case" consumer load profiles were applied to all utilities except California and New Jersey, for which the "High Case" load scenarios were used to better correspond with empirical data on state annual residential loads. Asterisks in Figure 2 for "California-PG\&E" and "New Jersey-JCP\&L" signify the application of these "High Case" load scenarios.
} 
the grid exports are applied against grid consumption, with the resulting difference constituting the amount of electricity the PV customer is billed for.

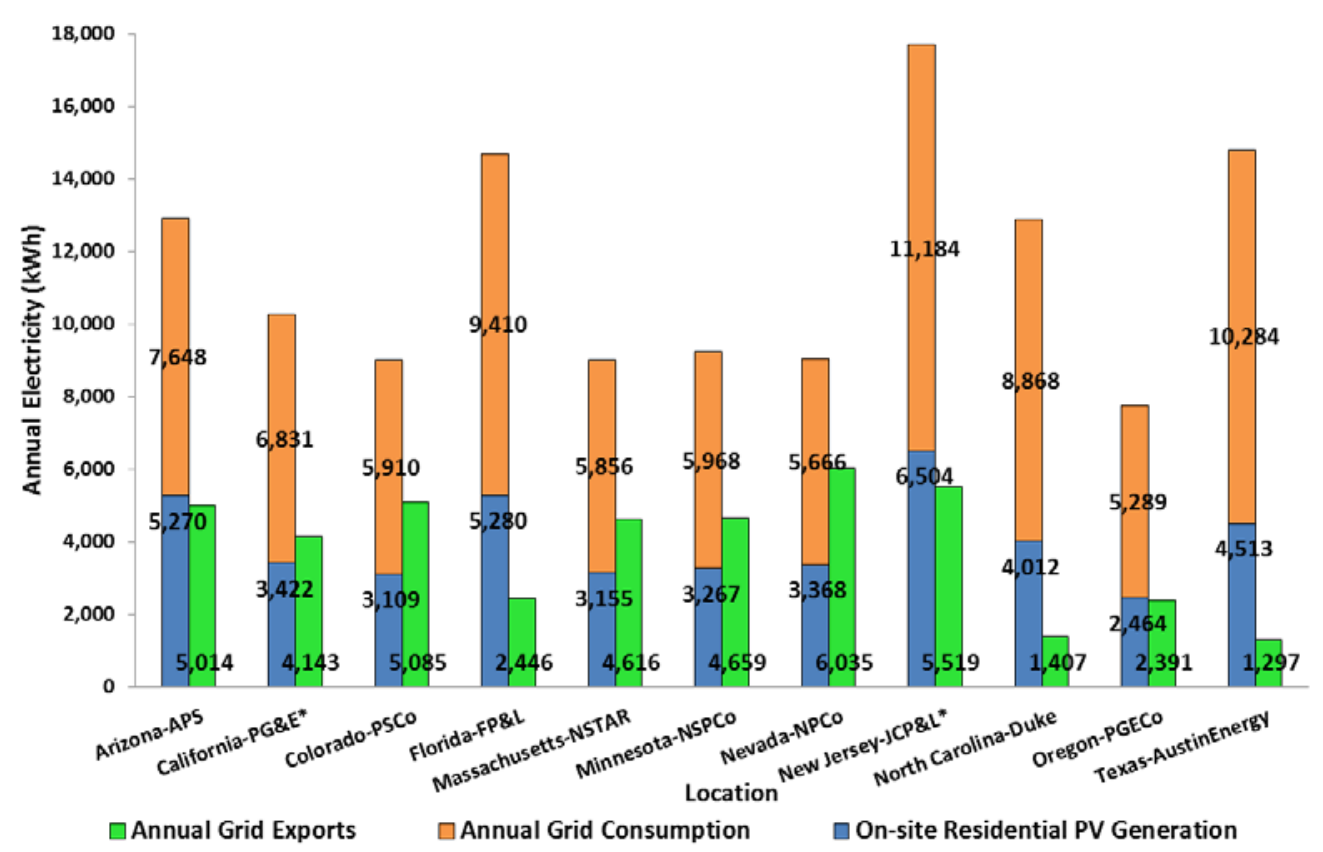

Figure 2. Annual modeled residential PV customer consumption and exports

Applying values from Figure 2 for representative customer load profiles and PV system sizes, in the modeled cases, an average of about $35 \%$ of residential PV customer's electricity demand is supplied by coincident, on-site PV production, with the remaining $\sim 65 \%$ met from grid-supplied electricity. Simulation results for Texas had the lowest fraction of on-site coincidental PV consumption, amounting to $30 \%$ of annual PV generation whereas Arizona has the highest coincidence, with $41 \%$ of annual generation consumed on-site. Results are somewhat driven by system size relative to load - smaller system sizes will enable a higher fraction of coincidental energy to household load.

Figures 3 and 4 present monthly grid consumption and export data, respectively, under "base" load profile conditions for average system sizes in Arizona, Colorado, Massachusetts, and New Jersey for a residential PV customer. Both consumption and exports impact the utilities, in different ways. A change in the electricity demanded potentially impacts the utility's ability to recover revenue from its customers. PV exports can impact utility operations since, depending on the contribution of PV exports to the grid at any given time, other generation resources could need to be ramped down or up, to balance system supply and demand.

Within Figure 3, the regional contrast of monthly residential electricity grid consumption is highlighted by an Arizona customer's substantial increase during the summer months, relative to the other states. Substantial air conditioning loads in the simulated data drive the spike in consumption during the Arizona and New Jersey summer. The overall lower Colorado and Massachusetts profiles reflect relatively limited cooling demands in the summer, and a reliance on natural gas heating during the winter months. The rise in electricity demand in the winter is largely attributed to increased demand from interior lighting. 


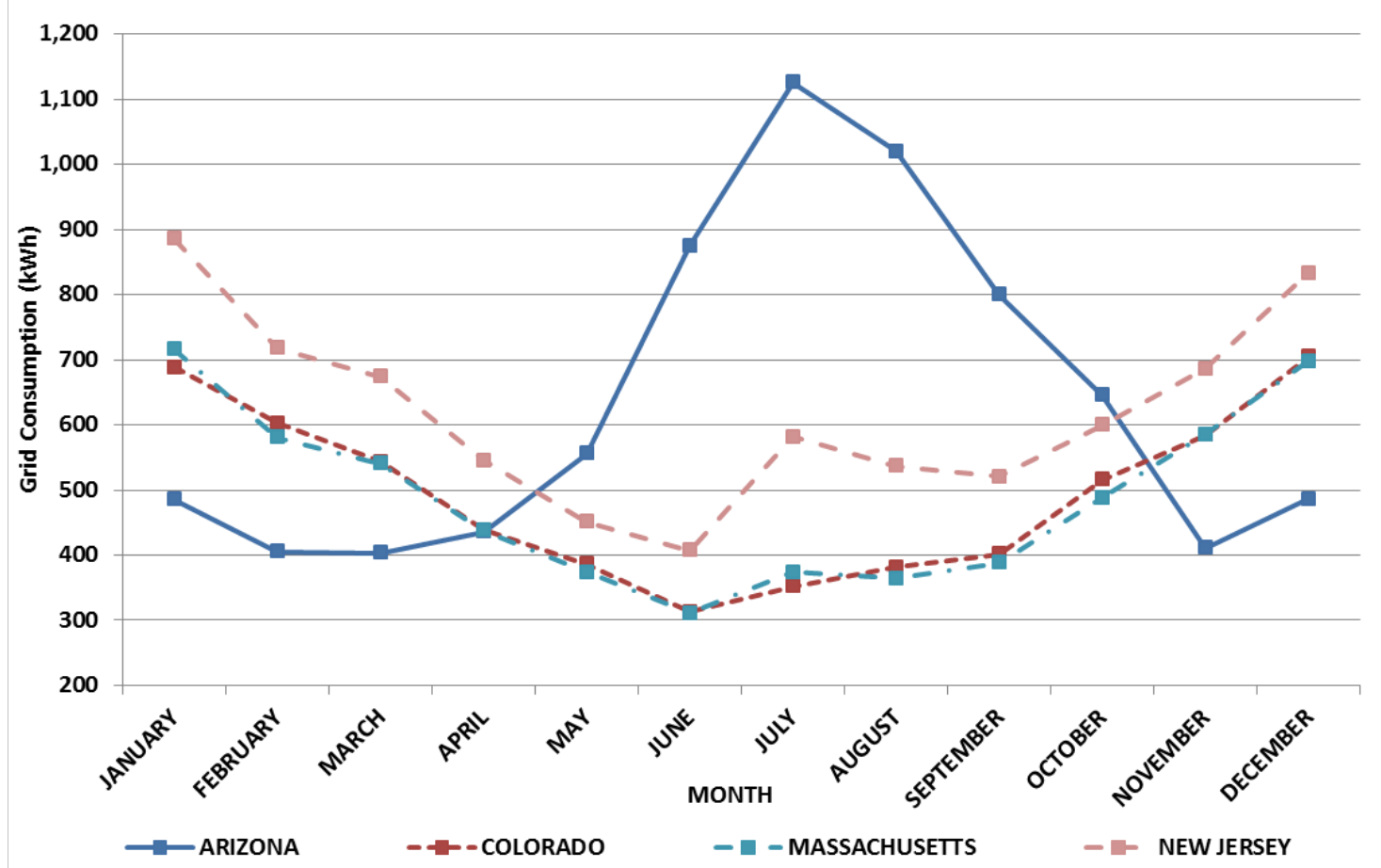

Figure 3. Modeled monthly PV customer grid consumption

Keeping these demand variations in mind, PV exports to the grid also vary considerably across the year and by region (Figure 4). For Colorado, exports are highest in the spring and summer months, when PV generation is high and customer lighting loads are lowest. Cooling loads in Colorado are present, but lower than the other states evaluated. In Arizona, the high demand for electricity for cooling during the summer substantially reduces PV exports during summer months. New Jersey, which has the largest average residential system size $(8.8 \mathrm{~kW})$, continues to export in the summer, even with high cooling loads as a result of high PV production relative to the rest of the year. PV exports are relatively consistent during the summer months for Colorado and Massachusetts customers, as the difference in their consumption and PV generation has little variation during this period. In an alternative depiction, Figure 5 overlays the grid consumption and grid export profiles for the average PV system sizes for both Arizona and Colorado. 


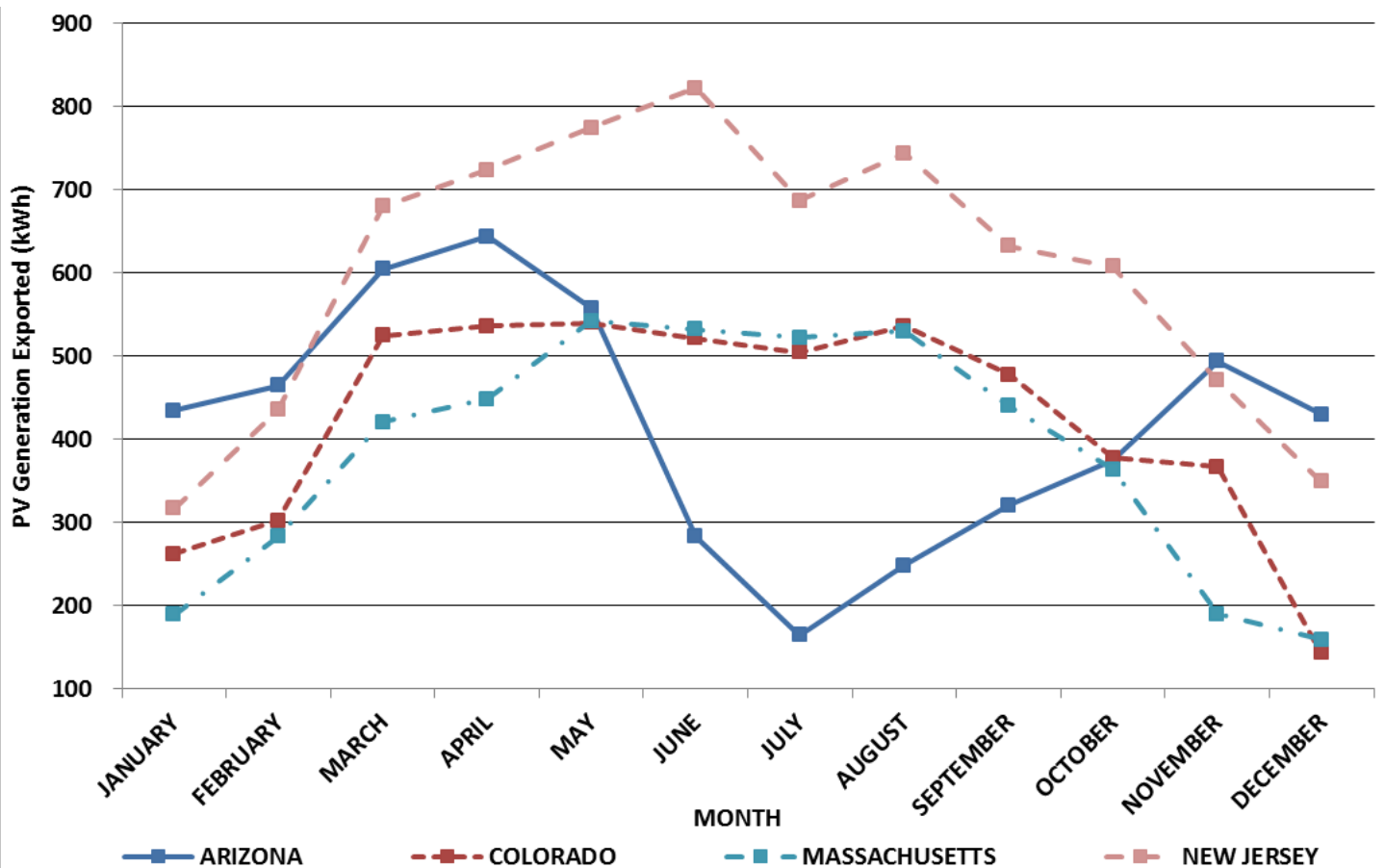

Figure 4. Modeled monthly PV Customer exports to the grid (CO, AZ, MA, NJ)
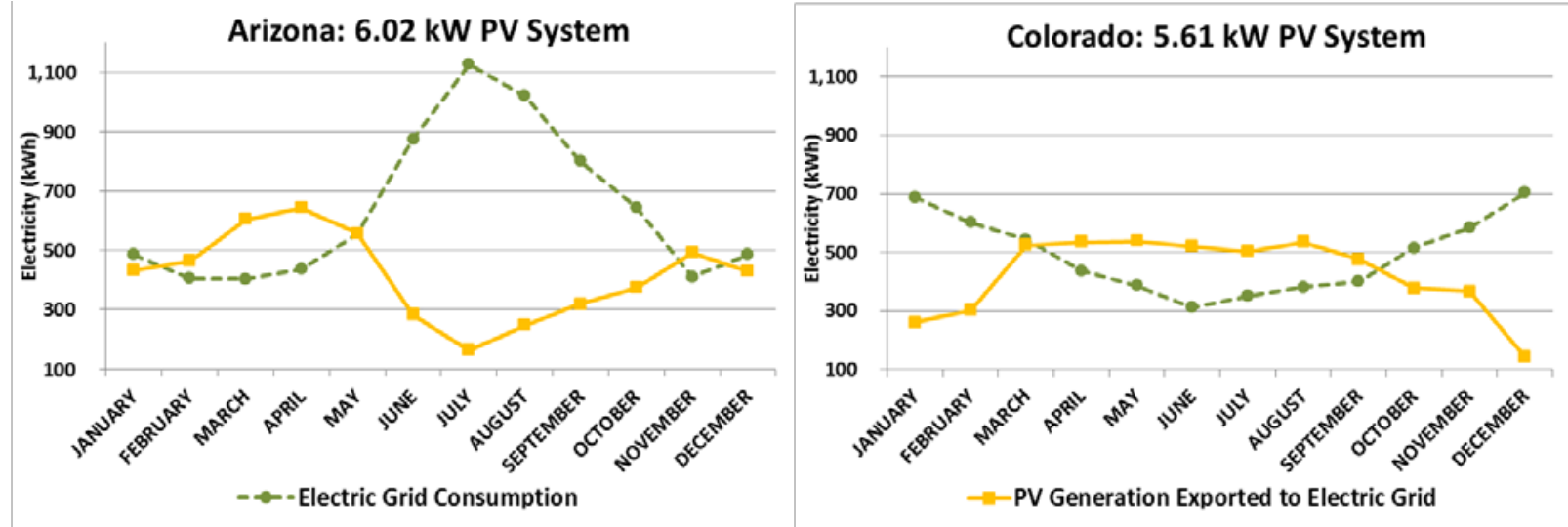

Figure 5. Modeled Grid Consumption and Grid Exports for Average PV System Sizes in Arizona and Colorado

These examples serve to illustrate the importance of grid interconnection to the operational viability of PV systems installed today. Overall, PV generation coincidence with actual demand was found to be low in many locations. If system sizes were increased to offset larger percentages of electricity demand, the amount of export to the grid would increase while grid consumption might also be reduced during particular periods of the day. While the degree of exports varies geographically, seasonally and with individual customer load profiles, the grid currently provides crucial pooling services for the average residential PV customer today.

The above findings on PV system sizes, percent off-set, and coincidence of generation with residential loads, and in particular the variations across locations, emphasizes the importance of collecting and evaluating data to develop estimates of the potential revenue shifting impacts of increased solar penetration. 


\section{Impacts of Rate Design Alternatives}

\subsection{Analysis of Rate Design Impacts}

Over the next several years, more rate cases aimed at addressing the impacts of distributed PV on utility fixed cost recovery are likely to be proposed. Evaluating impacts of any rate change requires complex analyses using utility and customer class-specific data. However, there is value in understanding high-level interactions and the parameters that are likely to come into play during these rate cases. For this portion of the analysis, we rely on simplifying assumptions for system sizing and rate design to evaluate 1) the impact of various rates on PV and non-PV customers and 2) how the impacts would differ according to the PV system size, regional load patterns, and the coincidence of PV production with load.

For a half a dozen utilities, we establish a 'baseline' by modeling the electric bill of a 'typical' PV and non-PV customer based on the actual standard or default residential rate as of spring 2015 and simulated load profiles (see Section 3). In order to reduce the number of variables impacting results, we model a $5 \mathrm{~kW}$ system, even though actual installed capacity may be higher or lower depending on the region. ${ }^{7}$

Then, we evaluate three rate types: increased fixed charges ( $\$ 10$ and $\$ 50)$, minimum bills $(\$ 10$ and \$50) and demand-based rates (demand charges), based on actual opt-in rates in each utility. The increased fixed charge and minimum bill rate mechanisms are generated by modifying the residential standard rate to include these components. As explained in the methodology section, the fixed charge and the minimum bill are modeled without reducing the energy rate.

\footnotetext{
${ }^{7}$ Results will be impacted by this in a few ways; for example, if system size is actually higher than modeled, minimum bills will be triggered more often.
} 
Table 4. Implementation of Rate Types in SAM

\begin{tabular}{|l|l|}
\hline Rate Type & Calculation \\
\hline Standard Rate & $\begin{array}{l}\text { Default residential tariff as of April } 2015 \text { is comprised of a base (fixed) charge and } \\
\text { an energy charge. All riders are included. } \\
\text { monthly rollover for customers where credits are valued at retail rates, for all } \\
\text { utilities. }\end{array}$ \\
\hline Fixed Charge & $\begin{array}{l}\text { Same as standard rate, but any existing fixed (customer) charge is increased by the } \\
\text { designated fixed charge amount }(\$ 10 \text { and } \$ 50) \text {. For example, if Utility X had an } \\
\text { existing fixed charge of } \$ 2.60 / \text { month, for the } \$ 10 \text { fixed charge scenario, \$10/month } \\
\text { would be added to yield a } \$ 12.60 / \text { month fixed charge. Assumes no additional } \\
\text { reduction in the per kWh energy rate. The fixed charge is also sometimes referred } \\
\text { to as a base-charge, customer charge or service-charge. }\end{array}$ \\
\hline Minimum Bill & $\begin{array}{l}\text { If the monthly bill would yield less than the minimum bill threshold, the difference } \\
\text { would be added to the bill (\$10 and } \$ 50) . \text { For example, if a } \$ 50 \text { monthly minimum } \\
\text { bill is in place, but a PV customer only has monthly charges of } \$ 35 \text { for that month, } \\
\text { then the customer pays an additional \$15 in order to meet the } \$ 50 \text { per month } \\
\text { minimum bill obligation. Assumes no additional reduction in the kWh energy rate. }\end{array}$ \\
\hline Demand-Based \\
Rate & $\begin{array}{l}\text { Specific utilities currently offer residential demand-based rates on an opt-in basis. } \\
\text { These rates are typically composed of a fixed charge, an energy charge, and a } \\
\text { demand charge. The energy charge is reduced relative to the energy charge in the } \\
\text { standard rate based on the public utility commission determination of a revenue- } \\
\text { neutral rate change. The demand charge is applied to the highest hourly demand in } \\
\text { each month. Our simulated load data is limited in that it only provides hourly } \\
\text { resolution. In reality, demand charges are often evaluated in tariff-specified sub- } \\
\text { hourly intervals (15 minutes or } 30 \text { minutes) and sometimes with ratchets }{ }^{10} \text { as long } \\
\text { as one year. }\end{array}$ \\
\hline
\end{tabular}

For the demand rate comparison, we analyze customer bill impacts in six of the nine utilities in the United States that have been known to offer voluntary residential demand-based rate structures (see Hledik 2014). We opted to use an existing tariff instead of developing a generic demand rate, due to the complexity and variability in current demand-based rate design. This hinders the ability to generalize results across utilities, so we walk through several results based on utility-specific dynamics. We selected utilities in different geographic regions in order to capture regional differences in both customer loads and local PV generation. We also attempted to select utilities that geographically aligned with the utilities evaluated in Section 4 of this analysis.

\footnotetext{
${ }^{8}$ A rate rider or adjustment is a temporary additional rate that appears on a utility bill, separate from the basic monthly rates. These are often used to recover excess energy costs or costs for a particular program, or to refund money on a temporary basis. These are typically calculated on a cents $/ \mathrm{kWh}$ basis, but can also be $\mathrm{kW}$-based, a flat fee, or a percentage of a rate component or overall bill.

${ }^{9}$ Actual net energy metering (NEM) policy varies by state, in some cases, by utility, in several of the following ways: NEM can vary in the period in which credits 'rollover' (typically monthly or annually), the value of rollover credits (typically retail rates or wholesale rates), and the value of any excess at the end of the true-up period (typically zero or wholesale rates), as well as limits on generating capacity.

10 "Demand ratchets" are a method used to establish the level of demand that a customer pays through a demand charge. Under a demand ratchet, the highest level of demand $(\mathrm{kW})$ utilized by a customer during a preceding time period (e.g., one year), will determine the level of demand for computing a customer's monthly demand change (Edison Electric Institute 2005).
} 
- Arizona Public Service (APS) - Phoenix, AZ

- Duke Energy Carolinas (Duke) - Raleigh/Durham, NC

- Georgia Power - Atlanta, GA

- Los Angeles Department of Water and Power (LADWP) - Los Angeles, CA ${ }^{11}$

- Public Service Company of Colorado (PSCo) - Denver, $\mathrm{CO}^{12}$

- Virginia Electric and Power Company (VEPCo) - Richmond, VA.

With the exception of APS, which has approximately $10 \%$ subscription, these demand rates have very low actual subscription. Note that these modeled impacts examined in the following analysis are limited to electricity bills only. However, PV system owners also incur costs associated with the ownership or leasing of the PV system, either as upfront costs, or through monthly loan or leasing payments. There are tradeoffs between the cost of a system and the value of reduced electricity bills at different system sizes. Rate structures and net metering policies further influence the bill savings associated with different system sizes; for example, tiered rate structures often encourage system sizing to offset most expensive tiers only. Figure 6 presents estimates of average monthly PV lease payments (per kW), based 2014-2-15 Energy Sage data (for states with sufficient data). ${ }^{13}$ The data suggest that lease payments vary substantially likely according to differences in location, system design, labor requirements, demand drivers and competitive pressure.

\footnotetext{
${ }^{11}$ Not included for the demand charge analysis since the LADWP demand charge rate only applies to multi-family housing.

${ }^{12}$ PSCo is an operating subsidiary of Xcel Energy that provides electric utility services to customers throughout Colorado. While in Colorado, PSCo is commonly referred to as 'Xcel Energy,' Xcel Energy is a utility holding company that serves customers in several states outside of Colorado.

${ }^{13}$ Not all states had sufficient data to estimate monthly payments - the identified states had at least 30 observations. This represents quoted monthly lease payments, not executed contracts. Nevertheless, assuming installers provide competitive quotes, these would be expected to be consistent with monthly payments on executed contracts.
} 


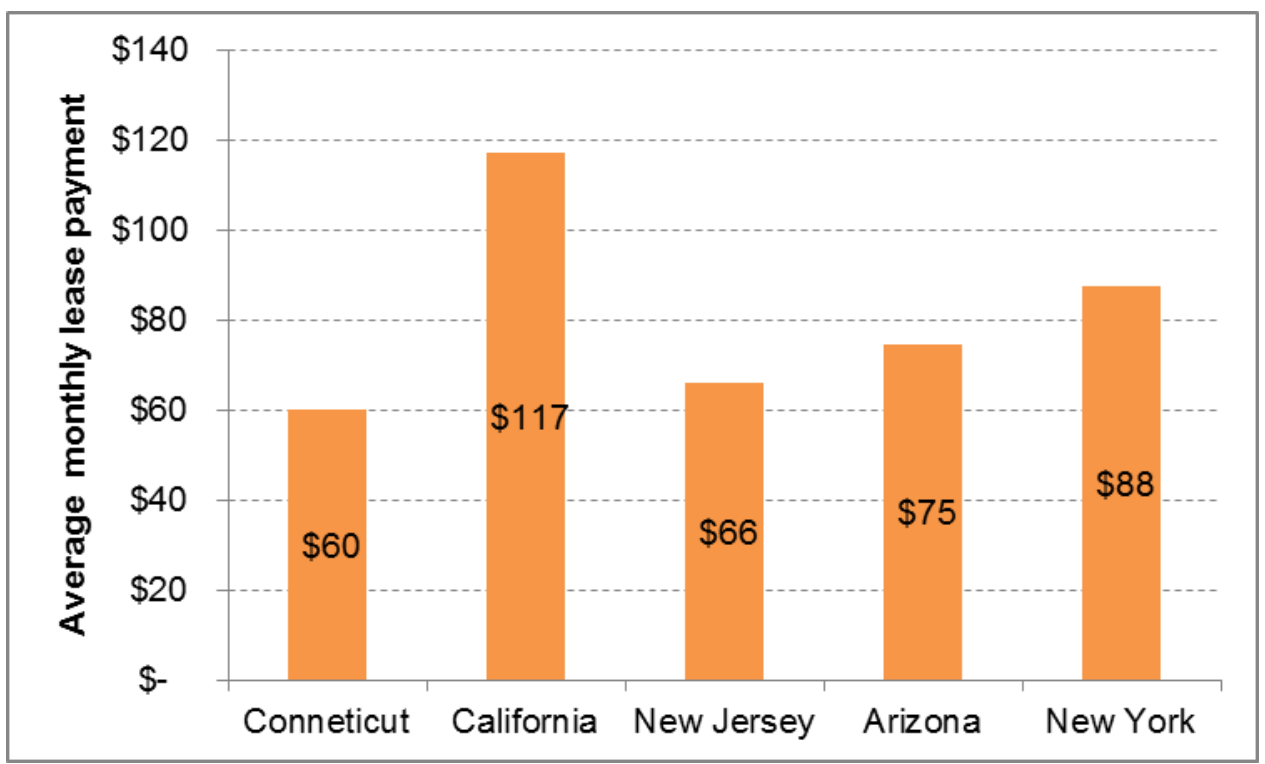

Figure 6. Estimated monthly residential PV lease payments for $5 \mathrm{~kW}$ systems by state Source: Energy Sage data

In order to evaluate full electricity-related costs incurred by solar customers, monthly solar costs on the order of $\$ 60$ - $\$ 117$ for a $5 \mathrm{~kW}$ system, depending on the state, should be added to the estimated monthly electric bill.

\subsection{Increased Fixed Charges}

Nearly all residential electricity customers pay a specified monthly customer charge on their electric bill that is independent of electricity usage. This is typically used to cover administrative costs such as billing and call centers, but not distribution infrastructure. Customer charges can range from a few dollars to over $\$ 40$ dollars, though the majority of rates fall between $\$ 10$ and \$20 (URDB 2015). The degree to which these charges are needed to enable recovery of utility fixed costs through existing rate structures has been increasingly debated. Declining electricity sales, due to increased energy efficiency, increased adoption of distributed generation, and other factors such as the recession, spurred a number of utilities to propose raising the fixed charge component of electricity rates (Lazar 2014b). The North Carolina Clean Energy Technology Center and Meister Consulting Group (NCCETS and Meister Consulting Group 2015) completed a thorough overview of recent changes to fixed charges.

Typically, an increase in a fixed charge for all customers is accompanied by a reduction in the energy charge, such that total utility revenues maintain revenue neutrality. However, when a fixed charge is proposed for net metered customers, energy rate reductions can be very small, or nonexistent, depending on the contribution of net metered customers to a utilities' revenue stream. Since changes to energy charges are utility and rate case-specific, we do not model any change in energy rates. 


\subsubsection{Comparison of Customer Impacts}

To understand the impacts of increased fixed charges on customer electric bills, we modeled residential PV customer electricity bills under the standard rate, and with a $\$ 10$ and $\$ 50$ increase to any existing monthly fixed charge.

Figure 7 presents the difference in the simulated annual utility electricity bills for the estimatedaverage, modeled residential PV customers for the standard rate and for the $\$ 10$ and $\$ 50$ increase in monthly fixed charge. The only change from the existing standard rate is that the electric bills are increased by the amount of the additional fixed charge. The increase for PV customers in all utilities relative to the standard bill lies between $14-17 \%$ for a $\$ 10$ fixed charge and $72-85 \%$ for a $\$ 50$ fixed charge, with the exception of PSCo, which models an increase 2-3 times as large as the other utilities. This is due to the fact that load profiles in PSCo are generally lower due to reduced HVAC loads from mild summer temperatures and the use of gas for heating during cooling months. Installing a 5-kW PV system will result in very low net demand from the grid, so an increase in a fixed charge will become a large proportion of the overall bill.

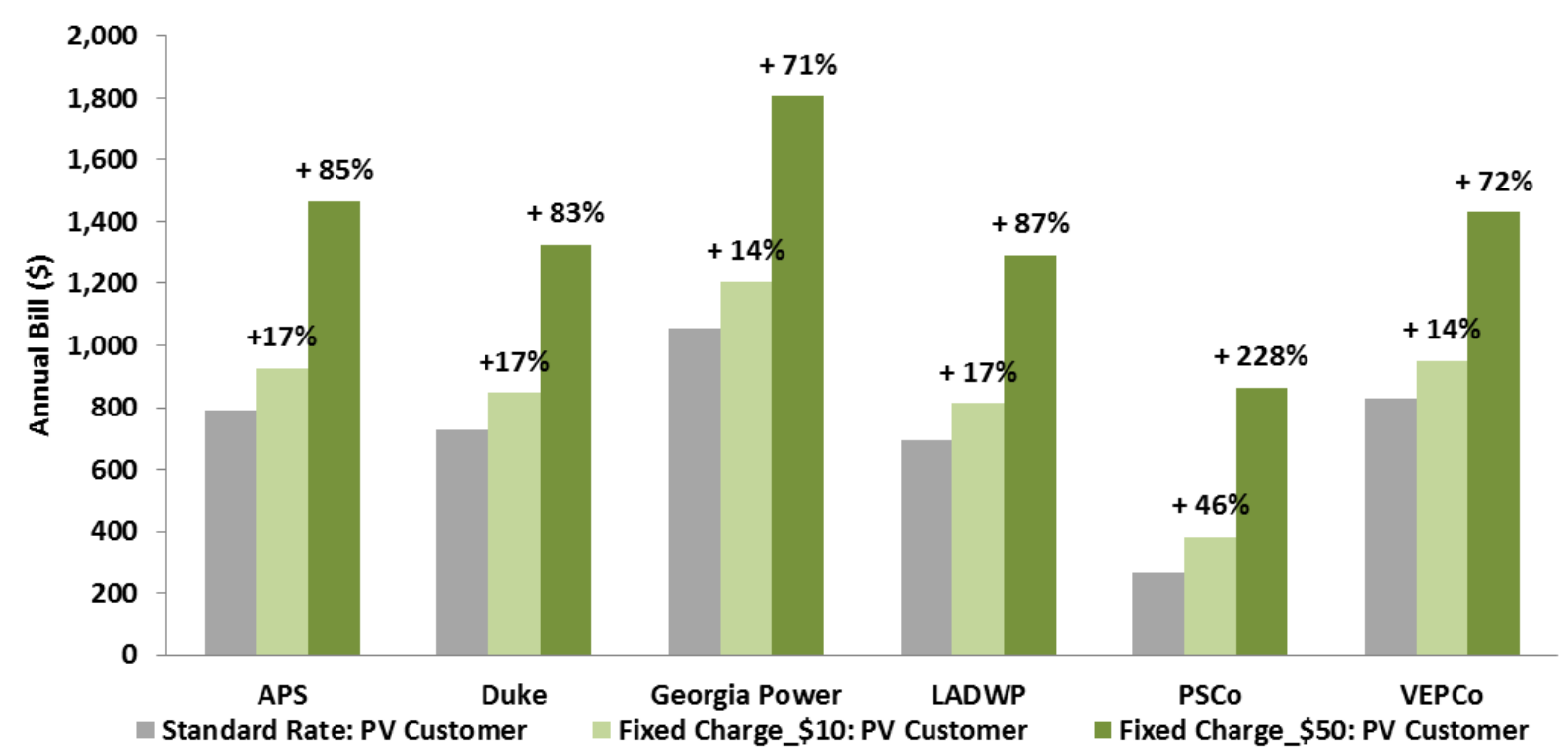

Figure 7. Modeled increased fixed charge impacts on residential PV customers ( $5 \mathrm{~kW}$ system size); $\$ 10$ and $\$ 50$ fixed charge increase, no corresponding energy charge reduction

Sources: SAM simulations, multiple utility tariffs

In reality, these rates may be associated with a corresponding reduction in energy charges, depending on the percentage of customers subject to the rate change. If accompanied by a reduced energy rate, these results would overestimate electricity bills; this overestimation would be more pronounced the more the customer continues to incur energy charges and the more the energy charge is reduced relative to the standard rate. For utilities like PSCo with already low energy use, the results would not vary substantially, even with a reduced energy charge. If the fixed charge is applied only as a 'standby charge' to cover distribution costs associated with households with solar, these results would appropriately reflect bill impacts. 


\subsubsection{Implementation Considerations}

Higher fixed charges are a straightforward and guaranteed mechanism to collect revenues to cover utility fixed costs (Kennerly 2014), but they are controversial because they can negatively impact low-income customers and can discourage both energy efficiency and self-generation. These effects are compounded as fixed charges comprise a larger portion of the total bill (Lazar 2014b).

When fixed charges are solely applied to net-metered customers, these can be called standby charges, and can be applied as a monthly cost, or an amount per kilowatt installed. A few jurisdictions have proposed or implemented increased fixed charges exclusively for PV customers. The Arizona Corporation Commission approved a $\$ 0.70$ monthly fixed charge per installed kW of PV capacity for Arizona Public Service net-metered customers, and it is now considering increasing that charge to $\$ 3.00 / \mathrm{kW}$ for new net-metered customers (APS 2015).

Disadvantages of standby charges are discussed in Stanton (2012) as well as Kennerly (2014). Critiques center around the bluntness of the design, which can result in a mis-allocation of costs over the short and long term. Namely, such charges offer only a piecemeal approach to recovering utility costs based on a snapshot of costs when a rate is passed and cannot reflect the costs or benefits associated with a particular household (Kennerly 2014).

\subsection{Minimum Bill}

A minimum bill rate design does not change the rate components of the standard bill, but specifies a minimum amount a customer will owe each billing cycle, regardless of the energy they use. For the majority of residential electricity customers without PV, the standard monthly bill, which includes the fixed charge plus an energy charge, will typically exceed this minimum. As such, a minimum bill rate would have no impact on the majority of customers (Lazar 2014b). However, a net-metered customer ${ }^{14}$ that has very low or no electricity purchases from the utility in a given month would still owe a minimal amount.

\subsubsection{Comparison of minimum bills with increasing fixed charges}

Figure 8 presents the difference in the simulated annual utility electricity bills for the average modeled residential PV customers for the standard rate and for the $\$ 10$ and $\$ 50$ increase in monthly fixed charge and a $\$ 10$ and $\$ 50$ minimum bill. Consistent with Greentech Media (2014), fixed charges results in substantially higher electricity bills for solar customers while minimum bills result in only slight increases.

\footnotetext{
${ }^{14}$ In addition to PV customers, seasonal customers (i.e., vacation homes) and vacant properties frequently have very low to no monthly energy consumption, for which a minimum bill rate would increase monthly bills.
} 


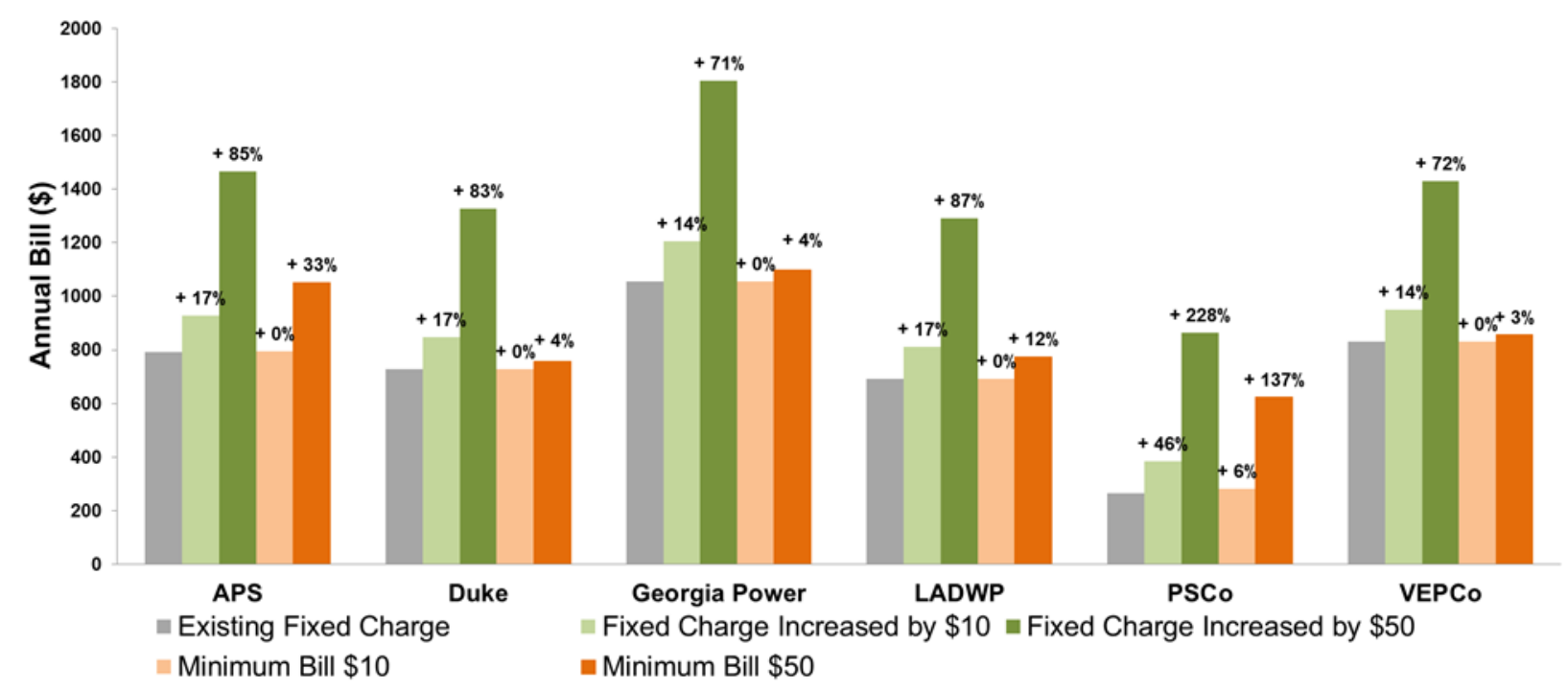

Figure 8. Modeled residential electric bill impacts (5 kW System Size); fixed charge increase and minimum bill of $\$ 10$ and $\$ 50$, no corresponding energy charge reduction

The $\$ 10$ minimum bill has no effect on the total annual cost for PV customers in all except the PSCo territory. The modeled PV customer in the PSCo territory sees a 6\% increase in the total annual utility bill, because the generation from a $5 \mathrm{~kW}$ system is sufficient to offset the full load in some of the summer months, triggering a minimum bill. In the other utility areas, electricity consumption is sufficiently high, due to variables such as air conditioning loads, such that the customer never offsets all of the electricity consumption over the course of a month and thus continues to incur monthly costs equal to at least the $\$ 10$ minimum bill.

Applying a \$50 minimum bill increases PV customer's annual utility costs (as compared to the standard rate) in all cases evaluated, although the effect varies considerably across utilities depending on the degree to which PV offsets the monthly load. The largest impact is the PSCo and APS service areas, where electricity loads are substantially offset by PV generation during spring months. In Duke, Georgia Power, LADWP, and VEPCo territories, the impact of the $\$ 50$ minimum bill is relatively modest, resulting in a 3-12\% annual cost increase over the standard rate: In those territories, the modeling estimates that most monthly bills would exceed $\$ 50$, anyway.

Figure 9 provides monthly detail regarding the impacts of a $\$ 50$ minimum bill in both the Virginia Electric and PSCo service areas. These represent the regions studied where a minimum bill has the least and the most impact on the PV customer's annual payments to the utility. In the case of a PV customer in the Virginia Electric territory, the \$50 minimum bill is only triggered in April, May and June. During these months, PV customers would otherwise see a monthly utility bill of only about $\$ 31-49$. In the PSCo case, the minimum bill takes effect in all but two months 
of the year (January and December). ${ }^{15}$ Without the minimum bill, net-metered customers would only pay the utility the standard customer charge of $\$ 8 /$ month, because the PV generation from a $5 \mathrm{~kW}$ system would offset all of the customer's monthly electricity consumption.

\begin{tabular}{|c|c|c|c|c|c|c|c|c|c|c|c|c|c|c|c|}
\hline \multicolumn{3}{|c|}{ PUBLIC SERVICE COMPANY OF COLORADO } & \multirow{2}{*}{$\begin{array}{l}\text { Jan } \\
\$ 101 \\
1\end{array}$} & Feb & \multirow{2}{*}{$\begin{array}{l}\text { Mar } \\
\$ 90\end{array}$} & Apr & \multicolumn{2}{|c|}{ May } & June & July & Aug & Sept & Oct & Nov & Dec \\
\hline \multirow{4}{*}{$\begin{array}{c}5 \mathrm{~kW} \\
\text { System }\end{array}$} & Standard & Monthly Bill WITHOUT PV & & $\$ 91$ & & $\$ 80$ & $\$$ & 76 & $\$ 71$ & $\$ 79$ & $\$ 81$ & $\$ 81$ & $\$ 82$ & $\$ 88$ & $\$ 100$ \\
\hline & Rate & Monthly Bill WITH PV & $\$ 56$ & $\$ 43$ & $\$ 18$ & $\$$ & $\$$ & 8 & 8 & & $\$$ & $\$$ & $\$$ & $\$ 25$ & $\$ 68$ \\
\hline & \multirow[b]{2}{*}{$\begin{array}{c}\text { Minimum } \\
\text { Bill } \$ 50\end{array}$} & Monthly Bill WITH PV & $\$ 56$ & $\$ 50$ & $\$ 50$ & $\$ 50$ & $\$$ & 50 & $\$ 50$ & $\$ 50$ & $\$ 50$ & $\$ 50$ & $\$ 50$ & $\$ 50$ & $\$ 68$ \\
\hline & & \begin{tabular}{|c|}
$\begin{array}{c}\text { PV Customer Bill Increase } \\
\text { from Standard Rate }\end{array}$ \\
\end{tabular} & $\$-$ & $\$$ & $\$ 32$ & $\$ 42$ & $\$$ & 42 & $\$ 42$ & $\$ 42$ & $\$ 42$ & $\$ 42$ & $\$ 42$ & $\$ 25$ & $\$$ \\
\hline \multicolumn{3}{|c|}{ VIRGINIA ELECTRIC \& POWER COMPANY } & Jan & Feb & Mar & Apr & \multicolumn{2}{|c|}{ May } & June & July & Aug & Sept & Oct & Nov & Dec \\
\hline \multirow{4}{*}{$\begin{array}{c}5 \mathrm{~kW} \\
\text { System }\end{array}$} & Standard & Monthly Bill WITHOUT PV & $\$ 149$ & $\$ 132$ & $\$ 131$ & $\$ 121$ & $\$$ & 117 & $\$ 136$ & $\$ 182$ & $\$ 163$ & $\$ 137$ & $\$ 121$ & $\$ 126$ & $\$ 138$ \\
\hline & Rate & Monthly Bill WITH PV & $\$ 101$ & $\$ 80$ & $\$ 61$ & $\$ \quad 44$ & $\$$ & 31 & $\$ 49$ & $\$ 90$ & $\$ 79$ & $\$ 62$ & & $\$ 78$ & $\$ 96$ \\
\hline & \multirow[b]{2}{*}{$\begin{array}{c}\text { Minimum } \\
\text { Bill } \$ 50\end{array}$} & Monthly Bill WITH PV & $\$ 101$ & $\$ 80$ & $\$ 61$ & $\$ 50$ & $\bar{s}$ & 50 & $\$ 50$ & $\$ 90$ & $\$ 79$ & $\$ 62$ & $\begin{array}{l}\$ 59 \\
\end{array}$ & $\begin{array}{ll}\$ 78 \\
\end{array}$ & $\$ 96$ \\
\hline & & $\begin{array}{c}\begin{array}{c}\text { PV Customer Bill Increase } \\
\text { from Standard Rate }\end{array} \\
\end{array}$ & $\$$ & $\$$ & $\$$ & & $\$$ & 19 & & $\$$ & $\$$ & $\$$ & $\$$ & $\$$ & $\$$ \\
\hline
\end{tabular}

Figure 9. Monthly bill comparison of modeled $\$ 50$ minimum bill and standard rate for example utilities

\subsubsection{Implementation Considerations}

Minimum bills are an option for directly addressing utility concerns over recovery of fixed cost, as they can ensure that customers contribute a minimum amount of revenue to the utility each month if their consumption is very low. For PV customers, minimum bills would be triggered only during those months when PV customers would otherwise contribute little to system costs, because of any combination of higher solar PV production and lower consumption. As a result, minimum bills provide a targeted method to address the fixed cost recovery issues associated with customer PV generation. In contrast, increasing fixed charges increases the costs to the PV customer in all months, regardless of the degree to which their PV system offsets their electricity purchases from the utility. Both minimum bills and fixed charges result in a disincentive for energy conservation for certain users, but in the case of a minimum bill, this would apply to only a small subset of customers (Lazar 2015). Kennerly (2014) suggests that compared to increased fixed charges, minimum bills more accurately capture the revenue adjustment required from lowusage customers.

The percentage of load displaced by solar critically drives the impact of a minimum bill (and how this varies with higher minimum bills). Relatively low system sizing assumptions in this analysis may underestimate bill impacts for systems that offset closer to $100 \%$ of load. For example, in Greentech Media's (GTM's) (2014) analysis of Massachusetts bills over a 3 month period, an increase of a $\$ 10$ to a $\$ 50$ minimum bill resulted in a 17 -fold increase in electric bills (from $\$ 12$ to $\$ 219$ more than current rates) for a system that offset $75 \%$ of load.

Again, we have modeled minimum bill rate adjustments without reducing the energy charge component of the bill. If a minimum bill was accompanied by a reduction in the energy charge component, the results of this analysis would overestimate electricity bills. This overestimation

\footnotetext{
${ }^{15}$ Simulated load profiles assume gas heating. In reality, many households in Colorado are all-electric, and these households may be more likely to adopt solar given a higher electric load. A gas-heated house may install a smaller system.
} 
would be more pronounced the more the energy charge is reduced, relative to the standard rate, and in cases where customers have low energy use (or with PV systems that off-set a large percentage of their load).

\subsection{Demand-based Rates}

Demand-based rates are composed of a demand charge in addition to the fixed charge and the energy charge. Demand charges have traditionally been levied on large commercial and industrial customers, but are increasingly being discussed as a rate option for residential and small commercial customers as well.

Large electricity users are well equipped to respond to such tariffs because they are more likely to have at least some ability to monitor and control demand levels. Historically, residential and small commercial and residential users have been less equipped to perform this monitoring and respond to the pricing signals that the rate structure provides. This is likely to change as home energy management technologies become more sophisticated and widespread. Another barrier has been the limited deployment of advanced metering capabilities ${ }^{16}$ for the smallest customers, which electricity providers need to record (and bill for) the hourly or sub-hourly customer demand data on which demand-based rates are calculated. As a result of these limitations, only about a dozen utilities have implemented residential demand charges to date, and these are typically being offered on an opt-in basis (Hledik 2014).

Demand charges are calculated based on the interval with the highest $\mathrm{kW}$ usage within a billing period. First, the interval with the maximum capacity demanded is identified. The capacity within that interval is then typically averaged. To derive the demand charge component of the rate, the average capacity for the interval is multiplied by the utility's demand charge rate for the time of day/season in which the interval occurred. For example, given a maximum capacity demand of $11 \mathrm{~kW}$ and a demand charge of $\$ 5 / \mathrm{kW}$, the demand charge component for the monthly bill for the example in Figure 10 would be $(11 * 5)=\$ 55$.

\footnotetext{
16 “Advanced metering capabilities" imply metering that has the ability to capture both kWh consumption as well as peak load. This can be done through time of use meters in addition to today's advanced metering infrastructure (AMI). For PV customers, a demand meter may be installed in place of a kWh meter as a method for assessing a demand-based rate on the customer (Linvill, Shenot, and Lazar, 2013a).
} 


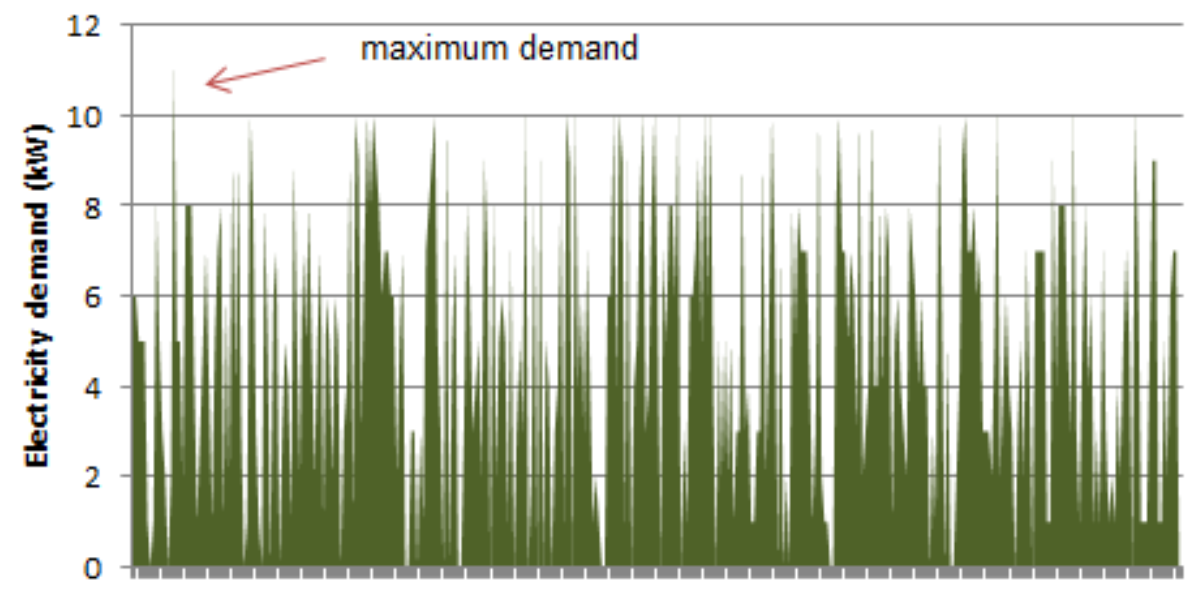

Hour intervals over one month

Figure 10. Illustrative hourly customer demand for a one-month period (not based on actual data)

Often, demand charge intervals are sub-hourly. Figure 11 illustrates how the time interval used by the utility to calculate the demand charge component of the bill can impact the customer's payments to the utility. The example shows the difference between the use of 15-minute, 30minute and hourly intervals, for a single, hypothetical demand curve. ${ }^{17}$ The level of demand at every moment throughout an interval is averaged over the entire interval. The smoothing effect of averaging the demand across the interval means that longer demand intervals result in lower 'peaks'. The solid green line in Figure 11, which depicts the demand curve after it is averaged using hourly intervals, depicts this smoothing effect. With shorter intervals, the spikes in demand are 'captured' and not as smoothed by the averaging of demand across the interval. This is represented by the dotted blue line, which shows how the load curves would be depicted using a 15-minute demand interval.

The degree to which the maximum demand varies by the length of the time interval is highly dependent on the load profile. In the case of a residential customer, this means that the way in which household appliances are used can greatly impact the load curve and the resulting demand charge. For example, running a clothes dryer would create steady demand over an hour, whereas the use of a hair dryer would create a short-term spike.

\footnotetext{
${ }^{17}$ Figure 11 was generated only to illustrate the concept of demand interval, it is not representative of typical demand patterns. While a typical billing cycle occurs over the course of a month, the simplified 5-hour "billing cycle" presented here has been created to illustrate how values, including the maximum measured demand, fluctuate under different demand intervals.
} 


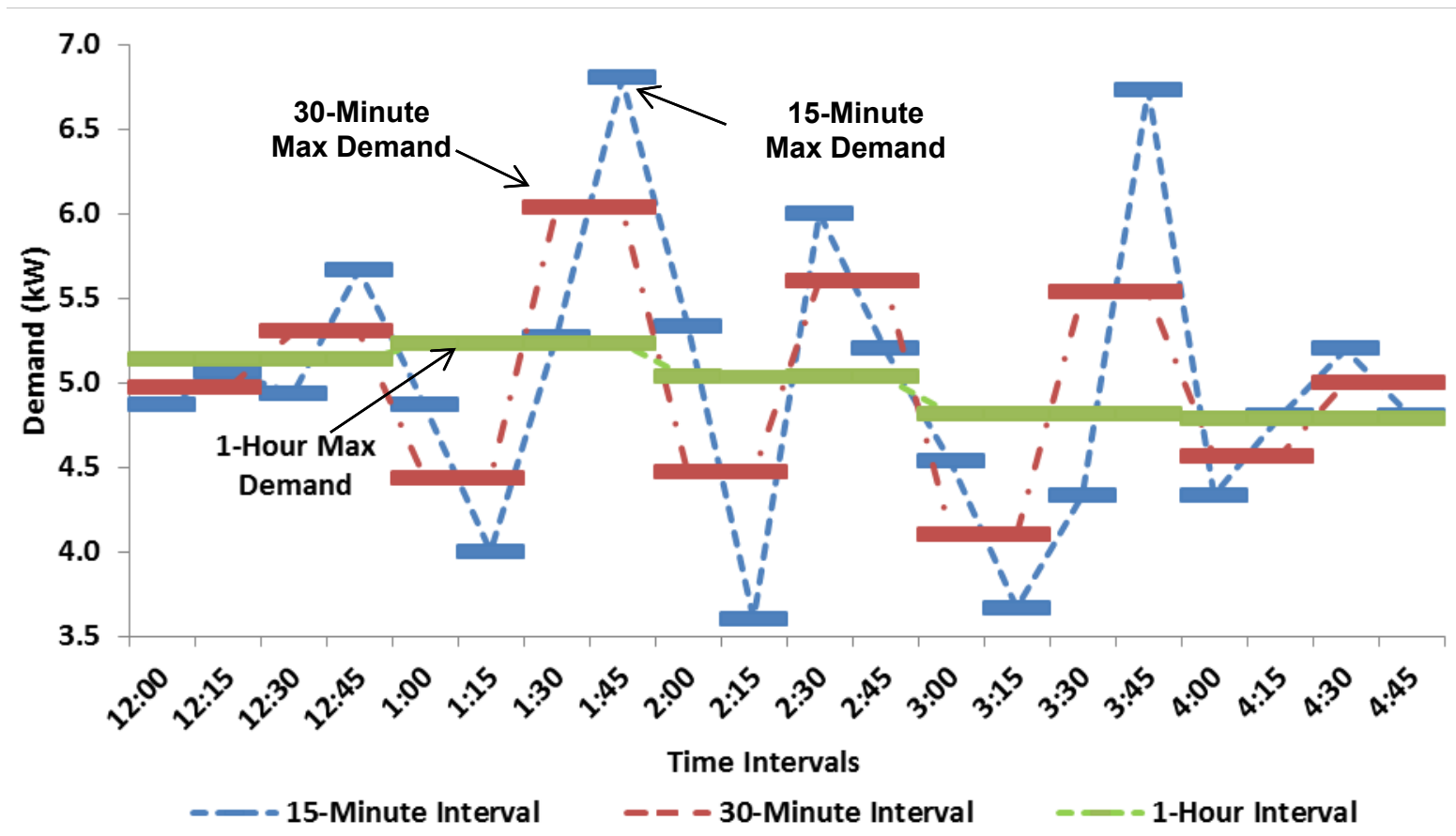

Figure 11. Demand Interval comparison: 15-, 30-, and 60-minute (1-hour) intervals across 5-hour "billing cycle" (illustrative, not based on actual data)

An important limitation in our analysis of demand-based rates is that SAM is only capable of modeling hourly consumption and PV generation profiles, while the majority of existing demand-based rates today are based on 15-minute or 30-minute intervals. This analysis cannot model sub-hourly variation in household load and PV generation. The more that variation within an hour exists, the more this analysis will underestimate the influence of the demand-based rate on the customer.

Opt-in annual demand charges currently implemented range from $\$ 1.50$ to $\$ 8.25 / \mathrm{kW}$. Like an energy charge, the demand charge can vary seasonally. Table 5 compares seasonal peak and offpeak periods for utilities that were identified as having demand charges, based on Hledik (2014). As Table 5 indicates, peak periods generally range from June through September and demand charges are often 1.5 or 2 times higher during these peak months. ${ }^{18}$ In peak season, demand charges range from $\$ 5.20 / \mathrm{kW}$ to $\$ 13.50 / \mathrm{kW}$. The corresponding energy charge is reduced based relative to the standard rate. Table 6 shows that energy charges under demand-based rates are generally on the order of $\$ 0.04-0.06 / \mathrm{kWh}$, compared to roughly $\$ 0.09-0.11 / \mathrm{kWh}$ for standard rates. Finally, demand-charges can also take the structure of a demand-based time of use rate, where the charge is lower during non-peak periods.

\footnotetext{
${ }^{18}$ Interestingly, some utilities have found that at the household level, peak demand appears to be seasonally random, and does not always correspond with peak usage system-wide (Stone, 2015). This has implications for the potential for demand-based rates to be effective at reducing utility peak demand.
} 
Table 5. Demand Charge by Peak/Off-Peak Period (all units in kW) for Utilities with Opt-in Demand Charges

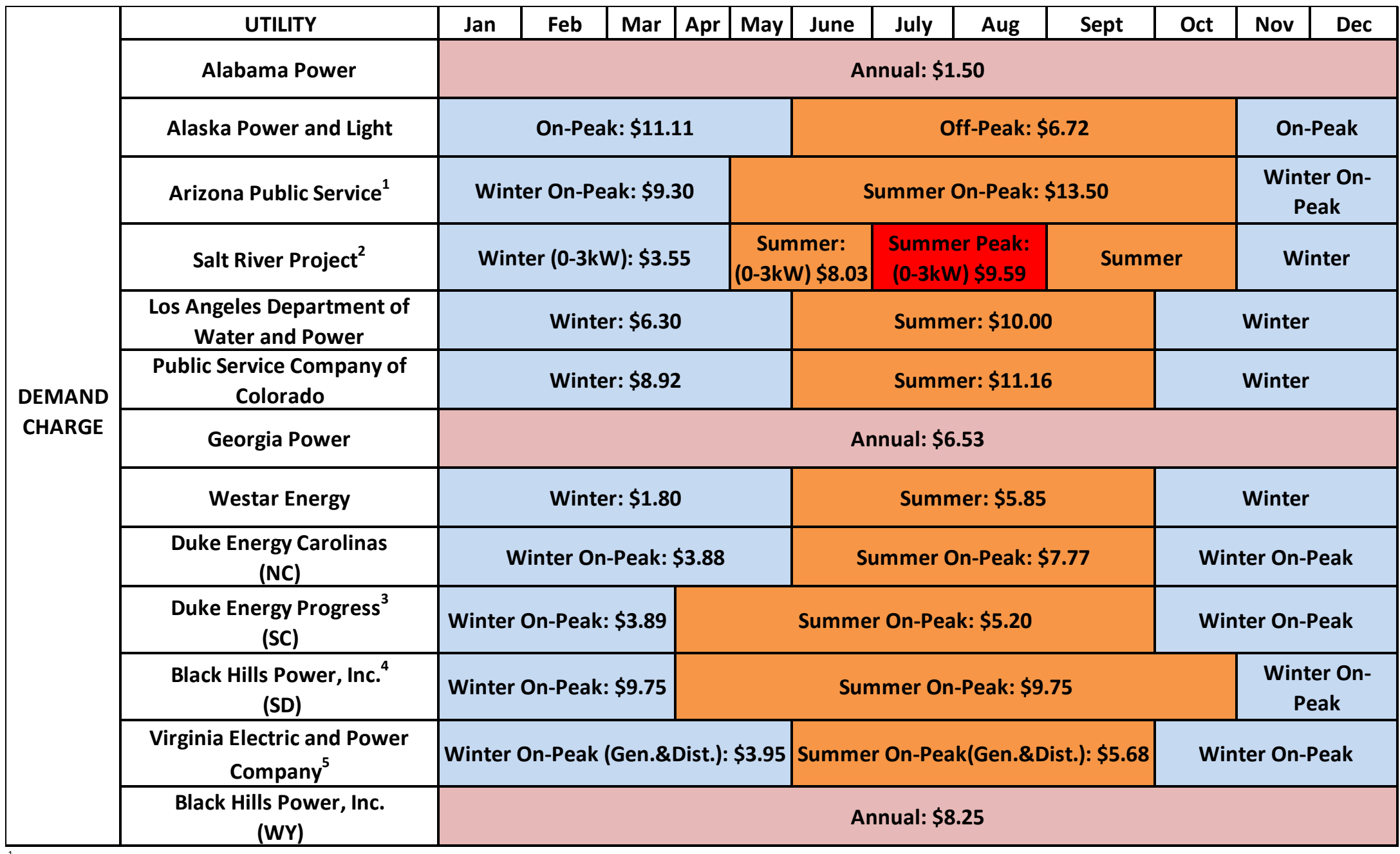

${ }^{1}$ Summer On-Peak (Weekdays; 12:00pm-7:00pm), Winter On-Peak (Weekdays; 12:00pm-7:00pm)

${ }^{2}$ Summer (0-3kW, $\left.\$ 8.03 ;>3-10 \mathrm{~kW}, \$ 14.63 ;>10 \mathrm{~kW}, \$ 27.77\right)$ ), Summer Peak (0-3kW, \$9.59; >3-10kW, \$17.82; >10kW, \$34.19), Winter $(0-3 \mathrm{~kW}, \$ 3.55 ;>3-10 \mathrm{~kW}, \$ 5.68 ;>10 \mathrm{~kW}, \$ 9.74)$

${ }^{3}$ Summer On-Peak (Weekdays: 10:00am-9:00pm), Winter On-Peak (Weekdays: 6:00am-1:00pm, 4:00pm-9:00pm)

${ }^{4}$ Summer On-Peak (Weekdays: 10:00am-10:00pm), Winter On-Peak (7:00am-11:00pm), Off-Peak (Exceeds 3.0 times On-Peak)

${ }^{5}$ Annual On-Peak Distribution Charge (\$1.612), Summer On-Peak Generation Charge (Weekdays: 11:00am-10:00pm, \$4.070), Winter On-Peak Generation Charge (Weekdays: 7:00-11:00am, 5:00-9:00pm, \$2.334)

Source: Utility tariffs $(2014 / 2015)$ 
Table 6. Comparison of Demand-based Rates and Standard Rates for Utilities with Opt-In Demand Charges

\begin{tabular}{|c|c|c|c|c|c|c|c|c|c|c|c|c|c|}
\hline \multirow{4}{*}{$\begin{array}{c}\text { State } \\
\text { Alabama }\end{array}$} & \multirow{4}{*}{$\begin{array}{l}\text { Utility Name } \\
\text { Alabama Power }\end{array}$} & \multicolumn{4}{|c|}{ Standard Rate } & \multicolumn{8}{|c|}{ Demand Charge Rate } \\
\hline & & \multirow{2}{*}{$\begin{array}{c}\text { Base } \\
\text { Charge }\end{array}$} & \multicolumn{3}{|c|}{ Base Energy Charge (\$/kWh) } & \multirow{2}{*}{ Base Charge } & \multicolumn{3}{|c|}{ Base Energy Charge (\$/kWh) } & \multicolumn{3}{|c|}{ Demand Charge (\$/kW) } & \multirow{3}{*}{$\begin{array}{l}\begin{array}{c}\text { Demand } \\
\text { Interval }\end{array} \\
15 \text { minute }\end{array}$} \\
\hline & & & Annual & Summer & Winter & & Annual & Summer & Winter & Annual & Summer & Winter & \\
\hline & & 14.50 & & 0.084 & 0.084 & 14.50 & 0.058 & & & $\$ \quad 1.50$ & & & \\
\hline Alaska & $\begin{array}{c}\text { Alaska Electric Light } \\
\text { and Power }\end{array}$ & 8.88 & & 0.098 & 0.119 & 11.49 & & $\$ \quad 0.058$ & $\begin{array}{ll}\$ & 0.051\end{array}$ & & 6.72 & $\$ 11.11$ & 15 minute \\
\hline Arizona & Arizona Public Service & 8.55 & & 0.097 & 0.094 & 16.68 & & $\$ \quad 0.044$ & $\$ \quad 0.041$ & & $\$ \quad 13.50$ & $\$ 9.30$ & 60 minute \\
\hline Arizona & Salt River Project & $\$ 18.50-\$ 20.00$ & & 0.110 & $\$ \quad 0.080$ & $\$ 30.94-\$ 45.44$ & & $\begin{array}{ll}\$ & 0.037\end{array}$ & $\$ \quad 0.039$ & & $\begin{array}{ll}\$ & 8.03\end{array}$ & $\$ \quad 3.55$ & 30 minute \\
\hline California & $\begin{array}{c}\text { Los Angeles } \\
\text { Department of Water } \\
\text { and Power }\end{array}$ & 10.00 & $\$ 0.071$ & & & 25.00 & & $\$ \quad 0.041$ & $\$ \quad 0.034$ & & $\$ \quad 10.00$ & $\$ \quad 6.30$ & Not Specified \\
\hline Colorado & $\begin{array}{c}\text { Public Service } \\
\text { Company of Colorado }\end{array}$ & 7.63 & $\$ 0.100$ & & & 13.85 & 0.054 & & & & 8.92 & $\$ 11.16$ & 15 minute \\
\hline Georgia & Georgia Power & 10.00 & $\$ 0.054$ & & & 10.00 & 0.010 & & & $\$ \quad 10.00$ & & & 30 minute \\
\hline $\begin{array}{c}\text { North } \\
\text { Carolina }\end{array}$ & $\begin{array}{c}\text { Duke Energy Carolinas, } \\
\text { LLC }\end{array}$ & 11.80 & $\$ 0.094$ & & & 13.38 & 0.057 & & & & 7.77 & $\$ \quad 3.88$ & 30 minute \\
\hline $\begin{array}{l}\text { South } \\
\text { Carolina }\end{array}$ & $\begin{array}{c}\text { Duke Energy Progress, } \\
\text { Inc. }\end{array}$ & 11.13 & & 0.106 & 0.096 & 9.60 & 0.056 & & & & 5.20 & $\$ \quad 3.89$ & 15 minute \\
\hline $\begin{array}{l}\text { South } \\
\text { Dakota }\end{array}$ & Black Hills Power, Inc. & 10.00 & $\$ 0.107$ & & & 14.00 & 0.232 & & & 9.75 & & & 15 minute \\
\hline Wyoming & $\begin{array}{l}\text { Black Hills Power, Inc. } \\
\text { (Wyoming Division) }\end{array}$ & 15.50 & $\$ 0.108$ & & & 15.50 & 0.064 & & & 8.25 & & & 15 minute \\
\hline Virginia & $\begin{array}{l}\text { Virginia Electric and } \\
\text { Power Company }\end{array}$ & 7.00 & $\$ 0.070$ & & & 12.00 & 0.028 & & & & 5.68 & $\$ \quad 3.95$ & 30 minute \\
\hline
\end{tabular}

Source: Hledik (2014), multiple utility tariffs (2014/2015) 


\subsubsection{Regional Comparison of Demand-based Rates}

The left-hand graphic of Figure 12 compares the energy bill for PV customers under the current standard rate versus the current opt-in demand-based rate for a half dozen utilities. The righthand graphic of Figure 12 shows the rate comparison for customers without PV. For customers with on-site PV, demand-based rates result in higher bills over the course of a year, although the magnitude of the impact varies substantially and depends upon the demand rate design, load profile, and the coincidence of $\mathrm{PV}$ production with load. For non-PV customers, demand-based rates generally result in decreased bills relative to the standard rate.
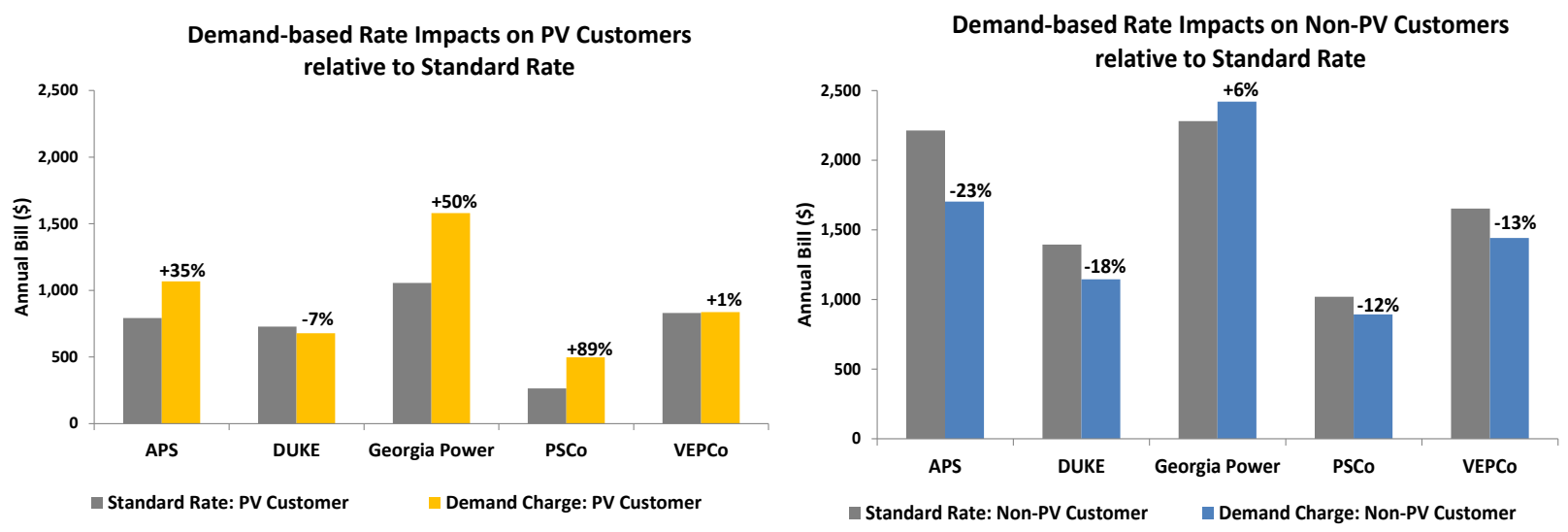
Figure 12: Modeled Comparison of Standard Rate to Demand Charge for PV and non-PV
Customers, based on actual tariffs

A mandatory or widely-adopted residential demand charge would be expected to have little to no effect on the average non-PV customers as it would be designed to maintain revenue neutrality. However, these voluntary demand charges were each designed in a unique context-in some cases, the objective was to encourage peak shaving for a subset of customers that chose to opt in. This could explain the decline in electric bills for non PV customers. ${ }^{19}$ Although these may not have been designed in the context of PV customers, dissecting the drivers behind these results illustrates the sensitivity of the bill impacts to differences in demand-based rate design.

To illustrate drivers of bill impacts, we illustrate the bill components of the two utilities with the largest proportional increases in annual electric bills under the demand-based rates examined APS and PSCo (Figure 13).

For 5kW PV customers in the APS service area, a large portion of the annual costs occur during the summer months due to heavy air conditioning loads; energy consumption during other parts of the year is much lower. The demand charge component of the bill is high $(\$ 13.50 / \mathrm{kW}$ in summer months). In addition, the fixed charge component in the demand-based rate ( $\$ 20 /$ month) is significantly higher than the fixed charge for the standard rate ( $\$ 8.55 / \mathrm{month})$. A PV customer under this demand-based rate would see an approximate 35\% increase in annual costs, compared

\footnotetext{
${ }^{19}$ Results may also underestimate bill impacts on all customer classes, including non-PV customers, due to the averaging of demand across hourly intervals.
} 
to the standard rate. For customers without PV, the demand-based rate results in a $23 \%$ bill decrease. $^{20}$

For PSCo, the large increase in the annual costs for $5 \mathrm{~kW}$ PV customers under a demand-based rate ( $89 \%$ increase from standard rates) is due to consistently low (or negative) net consumption resulting from a PV system that produces most of the household's electricity needs. Since there are little or no energy charges, the simulated PV customer's bill is mostly comprised of the demand and fixed charge components. Under a standard rate, this customer would have no energy charge for 8 months of the year. In contrast, a non-PV customer sees a $12 \%$ decline in annual costs under the demand-based rate structure. This is due to the lower energy charge component of the demand-based rate, relative to the standard rate (Figure 13).

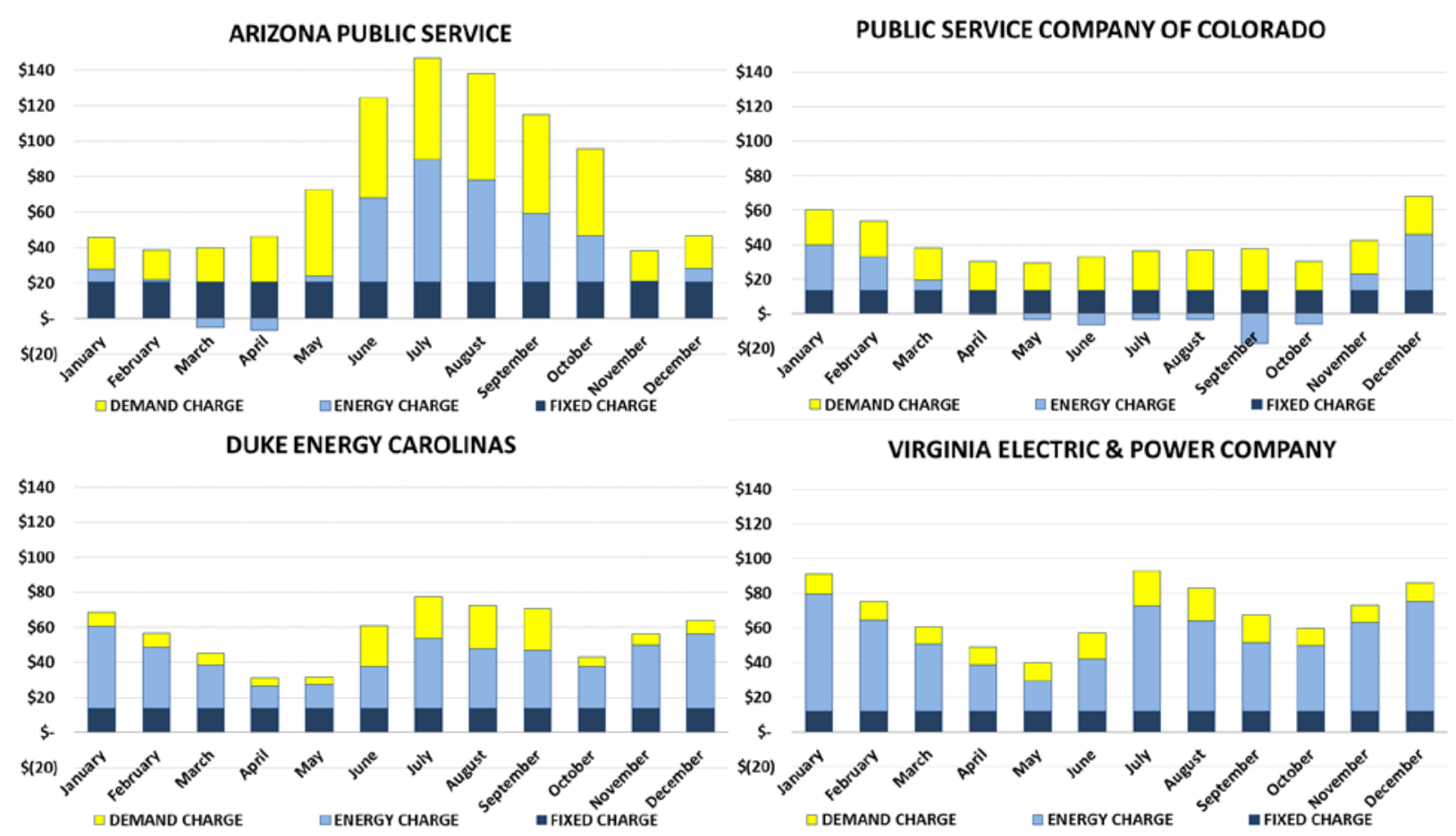

Figure 13. Modeled Demand Charge Bill Components for PV Customers of APS, PSCo, Duke, and VEPCo, based on actual tariffs

For utilities such as Duke and VEPCo, PV customers with $5 \mathrm{~kW}$ systems had smaller bill increases, or even declines in total costs, under the demand-based rate. A PV customer in Virginia Electric sees a modest (1\%) increase in electric bills, while a Duke PV customer sees a $7 \%$ decline. Figure 13 illustrates that the energy charge component of the monthly bills is still a significant driver of the overall cost for both of these utilities.

${ }^{20}$ It is important to note that this rate is a time-of-use rate that was designed to shift residential consumption out of on-peak time period, and with $11 \%$ of customers in the APS territory opting in, this rate has succeeded in this objective. However, few PV customers have selected this rate, most select a TOU rate. APS is currently developing a pilot project to evaluate how a customer with PV can use a demand rate more effectively with storage, energy efficiency and load management tools (Snook, 2015). 
In the case of Duke Energy Carolinas customers, the slight decline relative to the standard rate for PV customers is a result of lower net consumption when the demand rate is highest (JuneAugust). Net consumption is higher in winter months when demand rates are low, resulting in a low demand-charge component. The energy consumption that remains is charged at a reduced energy rate. For Virginia Electric customers, the demand charge is one of the lowest of the utilities evaluated, ranging from $\$ 3.95-\$ 5.68 / \mathrm{kW}$. Furthermore, there is only a minimal decrease in the corresponding energy charge. Figure 14 below quantifies the magnitude of these demand charge rate components relative to the monthly bill in the form of a heat map.

\begin{tabular}{|c|c|c|c|c|c|c|c|c|c|c|c|c|c|}
\hline UTILITY & RATE COMPONENT & Jan & Feb & Mar & Apr & May & June & July & Aug & Sept & Oct & Nov & Dec \\
\hline \multirow{3}{*}{$\begin{array}{l}\text { ARIZONA PUBLIC } \\
\text { SERVICE }\end{array}$} & Base Charge & $0.0 \%$ & $0.0 \%$ & $0.0 \%$ & $0.0 \%$ & $0.0 \%$ & $0.0 \%$ & $0.0 \%$ & $0.0 \%$ & $0.0 \%$ & $0.0 \%$ & $0.0 \%$ & $0.0 \%$ \\
\hline & \begin{tabular}{|l|} 
Energy Charge \\
\end{tabular} & $15 \%$ & $4 \%$ & $0 \%$ & $0 \%$ & $5 \%$ & $38 \%$ & $47 \%$ & $42 \%$ & $34 \%$ & $27 \%$ & $2 \%$ & $16 \%$ \\
\hline & Demand Charge & $40 \%$ & $43 \%$ & $48 \%$ & $55 \%$ & $67 \%$ & $45 \%$ & $39 \%$ & $43 \%$ & $48 \%$ & $51 \%$ & $45 \%$ & $40 \%$ \\
\hline \multirow{3}{*}{$\begin{array}{l}\text { DUKE ENERGY } \\
\text { CAROLINAS }\end{array}$} & Base Charge & $20 \%$ & $24 \%$ & $30 \%$ & $44 \%$ & $43 \%$ & $23 \%$ & $18 \%$ & $19 \%$ & $19 \%$ & $32 \%$ & $24 \%$ & $22 \%$ \\
\hline & Energy Charge & $68 \%$ & $62 \%$ & $54 \%$ & $40 \%$ & $42 \%$ & $40 \%$ & $52 \%$ & $47 \%$ & $47 \%$ & $55 \%$ & $64 \%$ & $66 \%$ \\
\hline & Demand Charge & $12 \%$ & $14 \%$ & $15 \%$ & $16 \%$ & $14 \%$ & $38 \%$ & $30 \%$ & $34 \%$ & $34 \%$ & $12 \%$ & $12 \%$ & $12 \%$ \\
\hline \multirow{3}{*}{ GEORGIA POWER } & Base Charge & $11 \%$ & $12 \%$ & $14 \%$ & $17 \%$ & $15 \%$ & $11 \%$ & $9 \%$ & $9 \%$ & $10 \%$ & $13 \%$ & $13 \%$ & $11 \%$ \\
\hline & Energy Charge & $34 \%$ & $27 \%$ & $24 \%$ & $13 \%$ & $11 \%$ & $29 \%$ & $34 \%$ & $37 \%$ & $31 \%$ & $20 \%$ & $28 \%$ & $32 \%$ \\
\hline & Demand Charge & $20 \%$ & $22 \%$ & $22 \%$ & $25 \%$ & $27 \%$ & $22 \%$ & $21 \%$ & $20 \%$ & $21 \%$ & $24 \%$ & $21 \%$ & $21 \%$ \\
\hline \multirow{3}{*}{$\begin{array}{l}\text { PUBLIC SERVICE } \\
\text { COMPANY OF } \\
\text { COLORADO }\end{array}$} & Base Charge & $23 \%$ & $26 \%$ & $36 \%$ & $46 \%$ & $47 \%$ & $42 \%$ & $38 \%$ & $37 \%$ & $37 \%$ & $45 \%$ & $33 \%$ & $20 \%$ \\
\hline & Energy Charge & $43 \%$ & $36 \%$ & $15 \%$ & $0 \%$ & $0 \%$ & $0 \%$ & $0 \%$ & $0 \%$ & $0 \%$ & $0 \%$ & $22 \%$ & $47 \%$ \\
\hline & Demand Charge & $34 \%$ & $38 \%$ & $49 \%$ & $54 \%$ & $53 \%$ & $58 \%$ & $62 \%$ & $63 \%$ & $63 \%$ & $55 \%$ & $46 \%$ & $32 \%$ \\
\hline \multirow{3}{*}{$\begin{array}{l}\text { VIRGINIA ELECTRIC \& } \\
\text { POWER COMPANY }\end{array}$} & Base Charge & $13 \%$ & $16 \%$ & $20 \%$ & $24 \%$ & $30 \%$ & $21 \%$ & $13 \%$ & $14 \%$ & $18 \%$ & $20 \%$ & $16 \%$ & $14 \%$ \\
\hline & \begin{tabular}{|l|} 
Energy Charge \\
\end{tabular} & $74 \%$ & $70 \%$ & $64 \%$ & $55 \%$ & $44 \%$ & $53 \%$ & $65 \%$ & $63 \%$ & $59 \%$ & $63 \%$ & $70 \%$ & $73 \%$ \\
\hline & Demand Charge & $12 \%$ & $14 \%$ & $16 \%$ & $21 \%$ & $26 \%$ & $26 \%$ & $22 \%$ & $23 \%$ & $24 \%$ & $17 \%$ & $14 \%$ & $13 \%$ \\
\hline
\end{tabular}

Figure 14: Relative magnitude of demand, energy and fixed charge components of monthly electric bill for modeled PV customers

\subsubsection{Implementation Considerations}

By design, demand-based rates aim to better align revenue collection with peaks in customer demand. Generally, these have been more widely used for commercial customers because the peak demand has more impact on the utility planning and resource decisions, whereas variability in residential usage tends to average out across users. Demand rates do not discourage energy efficiency, and are generally not as burdensome on low-income customers as high fixed charges. However, structuring demand charges requires decisions on the following parameters:

- The demand interval

- Whether different charges exist for coincident and non-coincident peak demand

- Whether demand charge varies seasonally

Demand charges require utilities to record and analyze large quantities of time-interval customer demand data in order to be able to bill customers accordingly. As utilities integrate advanced metering systems across their territories, demand-based rates and other less conventional rate designs will be viable options.

But if demand-based rates are intended to encourage customer behavior change, it is essential that customers understand the rate design, be able to access and evaluate their own energy demand profiles, and be able to respond to the pricing signals. Without these capabilities, customers are unable to control their usage and reduce their risk for incurring large or 
unanticipated demand-based costs. Even with automated controls, certain customers may not be capable of responding to demand-based rates (e.g., those with medical requirements or little control over their energy use). While PV systems can peak-shave on the average day if production aligns with peak load, only one cloudy hour a month resulting in low generation during household peak could nearly negate any demand-based bill reduction resulting from PV.

Demand-based rates, as with all rate structures, are designed by utilities and their regulators based on their unique objectives at the time they are implemented. Regulators may need to consider whether their specific objectives can indeed be achieved using demand-based rates. 


\subsection{Comparison Across Rate Alternatives}

All of the evaluated rate types have been proposed to address fixed cost recovery for net metered customers. Actual bill impacts for an implemented rate will depend on the details that emerge in a rate case as well as the particular load and generation profile of a given customer. This analysis implements a few simplifying assumptions in order to provide high-level insight into potential impacts and drivers of rate changes. Figure 15 compares the electricity bill impacts for a PV customer with a $5 \mathrm{~kW}$ system under the standard rate, increased fixed charge, minimum bill, and demand-based rates.

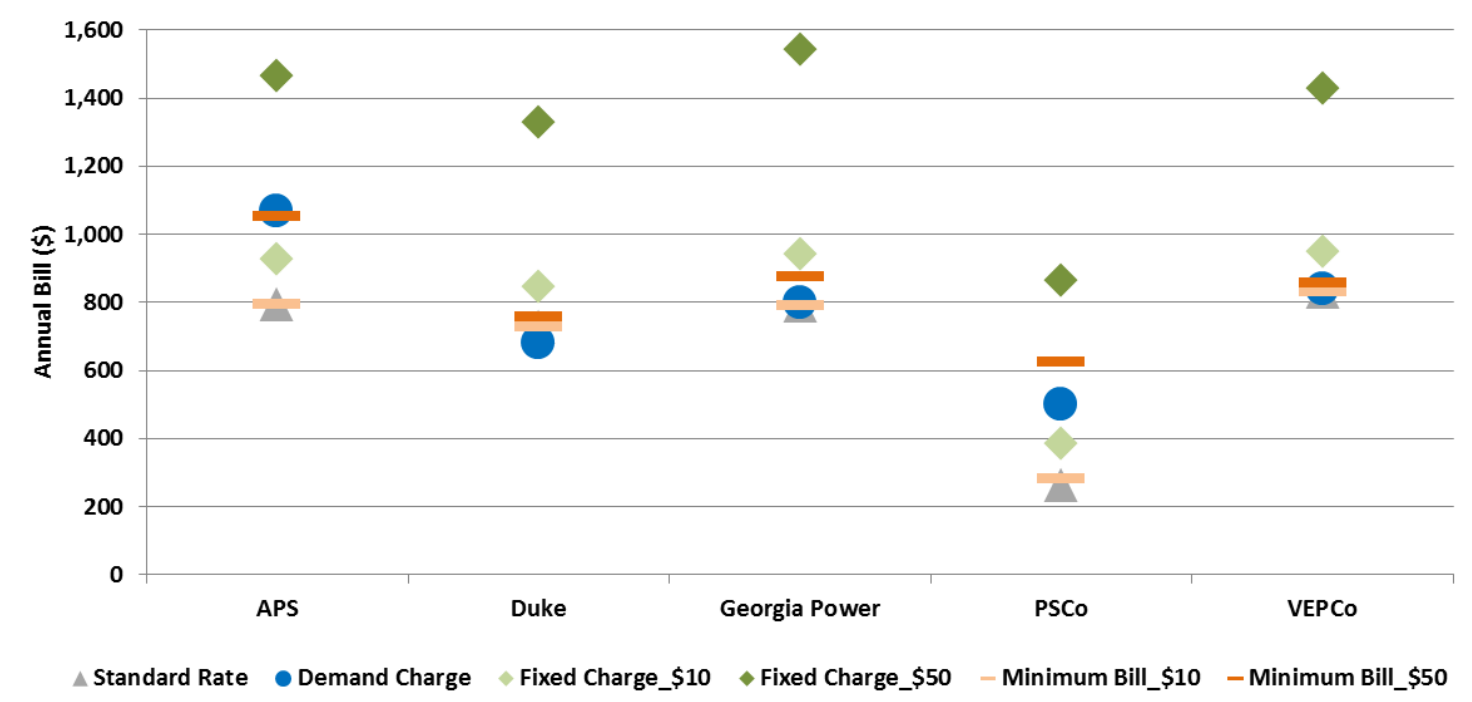

Figure 15. Annual residential PV customer bill comparison (modeled) of various rate structures across five utilities

Increasing the fixed charge by $\$ 50$ without any reduction in energy charge results in the most substantial increase in the annual electricity bill, in all regions. The other rate options are more closely aligned, in most of the utility service areas examined. Instituting a $\$ 10$ minimum bill increased costs the least, across most utility service areas.

For PV customers, demand-based rates resulted in limited electricity bill changes for all utilities except APS and PSCo. The generation and production profiles in the respective regions partially explain the differences - PV offsets a very large fraction of consumption in some months in the Western utility service areas. PV generation (based on modeled system sizes) offsets less household consumption in the Eastern utility area where consumption remains substantial even in periods of peak PV production. Some of the difference might also be inherent in the broader tariff design and the context in which it was created; some of the tariffs were developed years ago and others, like that of APS, are more recent. 


\section{Conclusions}

Utilities are increasingly considering alternative rates structures that are designed to recover fixed utility from residential PV customers with low net electricity consumption. Proposed structures have included fixed charge increases, minimum bills, and increasingly, demand rates for net metered customers and all customers. While at current levels of residential PV penetration, the revenue impacts of distributed generation are minimal in most areas, revenue impacts are anticipated to become a growing concern as distributed PV continues to increase. This paper provided high-level analysis of how different rate structures may impact electricity bills, and illustrated key drivers that ultimately affect the magnitude of impacts.

In the states evaluated, systems typically offset from just under two-thirds to nearly all of a particular household's load. While the degree of exports varies geographically, seasonally and with individual customer load profiles, the grid currently provides crucial pooling services for the average residential PV customer today. However, the typical PV customer is generally highly reliant on the grid to meet load that is not coincidental with PV production. Although some load and PV generation occur simultaneously, roughly $65 \%$ of a typical customer's electricity demand is non-coincidental.

Analysis of the impacts of rate changes found that fixed charges and minimum bills increase customer costs, regardless of system size or the degree to which PV off-sets customer load. Raising the fixed charge increased customer bills irrespective of consumption, whereas minimum bills only impacted customers in months when they used little grid-supplied electricity. Minimum bills had a negligible impact on customer bills, except in the case of customers that off-set a high percentage of their load with PV generation.

Demand charges resulted in an increase in utility bills of $35 \%$ or higher for PV customers in three of the five utilities evaluated. In the remaining three utilities, changes were either minimal (1\%) or slightly decreased. The impact of demand-based rates on customer bills critically depended on the rate design, load profile and coincidence of PV production with load. Demandbased rates varied significantly in terms of the charge components (demand charge, fixed charge, and reduction in energy charge) as well as the rate design (demand interval and temporal structure). All of the tariffs designed are opt-in and likely had specific objectives that were unrelated to solar customers.

Rate design must be carefully considered within the context of the objectives of a specific utility and ratepayers. Considerations include the extent to which they address utility revenue requirements and cost of service and their long-term impact on all customer classes. If a rate is intended to modify the timing and amount of electricity consumption, the extent to which customers understand the rate structure and are able to respond to the pricing signals it sends must be carefully considered.

Note that this analysis does not serve to be a definitive ranking of rate options, rather, serves to illustrate important considerations for the rate design process. This analysis was data-limited in several key areas. First, our load and production data were not available sub-hourly, underestimated the cost of sub-hourly demand charges. Second, we relied on simulated load profiles that may not reflect 'typical' profiles for net metered customers to the extent that net 
metered customers have different electricity consumption behaviors and aggregate needs. Variables that may differentiate net metered customers from non-net metered customers include, but are not limited to: appliance number and energy demand, age of housing stock, electricity conservation habits and energy efficiency investments. Third, due to the lack of information that would be typically made available in a rate case, energy charges were not reduced with corresponding modeled increased fixed charges and minimum bills.

These limitations illustrate the need for utilities to collect representative data on load profiles and PV production, at the time interval specified in the proposed tariff, to understand electricity consumption patterns of net metered customer and potential load shifting impacts. Further, as the solar industry expands and moves into new market segments, it will be important to consider the impacts of rate changes on new customer types. Finally, pilot tests may still be necessary to understand customer behavior change under new rate designs. 


\section{References}

American Council for an Energy-Efficient Economy (ACEEE). (2015). "Standby Rates." Accessed May 27, 2015: http://aceee.org/topics/standby-rates.

APS. (2015). "APS asks to reset grid access charge for future solar customers." Accessed May 27, 2015: https://www.aps.com/en/ourcompany/news/latestnews/Pages/aps-asks-to-reset-gridaccess-charge-for-future-solar-customers.aspx.

California ISO. (2013). "What the duck curve tells us about managing a green grid." California Independent System Operator. CommPR/HS/10.2013. Accessed June 1, 2015: https://www.caiso .com/Documents/FlexibleResourcesHelpRenewables_FastFacts.pdf.

California Public Utilities Commission. (2015). Decision on Residential Rate Reform for Pacific Gas and Electric Company, Southern California Edison Company, and San Diego Gas \& Electric Company and Transition to Time-Of-Use Rates. Proposed Decision, R.12-06-013 ALJ/JMO/JMH/jt2 (April 21, 2015): Accessed May 4, 2015: http://docs.cpuc.ca.gov/Published Docs/Efile/G000/M151/K305/151305677.PDF.

Cornfeld, J.; S. Kann. (2014). "Why a Minimum Bill May Be a Solution to Net Metering Battles." Greentech Media Inc.. Accessed January 14, 2015:

http://www.greentechmedia.com/articles/read/why-the-massachusetts-net-metering-compromisecould-be-a-model-for-other-st.

Costello, K. (2015). "Major Challenges of Distributed Generation for State Utility Regulators." Electricity Journal (28, 3); pp. 8-25. April 2015. Accessed April 17, 2015: http://ac.elscdn.com/S1040619015000378/1-s2.0-S1040619015000378-main.pdf? tid=0afae084-04d2-11e5af0b-00000aacb362\&acdnat $=1432773767$ 5be5582cbe037c9310a742b070ba5234.

Darghouth, N.; Barbose, G.; Wiser, R. (2014). "Customer-economics of residential photovoltaic systems (Part 1): The impact of high renewable energy penetrations on electricity bill savings with net metering."Energy Policy (67); pp. 290-300. Accessed April 12, 2015: http://ac.elscdn.com/S0301421513013062/1-s2.0-S0301421513013062-main.pdf? tid=c9d999aa-04cd11e5-9e50-00000aab0f27\&acdnat=1432771940 0aa718727ffc8ccd1d510f049c793640.

Darghouth, N.; Wiser, R.; Barbose, G.; Mills, A. (2015). Net Metering and Market Feedback Loops: Exploring the Impact of Retail Rate Design on Distributed PV Deployment. LBNL183185. Berkeley, CA: Lawrence Berkeley National Laboratory. Accessed July 2, 2015: http://eetd.lbl.gov/sites/all/files/lbnl-183185_0.pdf.

Denholm, P.; Margolis, R.; Ong, S.; Roberts, B. (2009). Break-even Cost for Residential Photovoltaics in the United States: Key Drivers and Sensitivities. NREL/TP-6A2-46909. Golden, CO: National Renewable Energy Laboratory. Accessed February 9, 2015: http://www.nrel.gov /docs/fy10osti/46909.pdf.

Gilman, P.; Dobos, A. (2012). System Advisor Model, SAM 2011.12.2: General Description. 18 pp.; NREL Report No. TP-6A20-53437. 
Hendron, R.; Engebrecht, C. (2010). Building America House Simulation Protocols. NREL/TP550-49426. Golden, CO: Prepared by the National Renewable Energy Laboratory for the U.S. Department of Energy Building Technologies Program. Accessed February 21, 2015: http:/www.nrel.gov/docs/fy11osti/49246.pdf.

"Historical Loads." (2015). SNL Financial. Accessed February 2, 2015: https://www.snl.com/interactivex/e analytics hourly.aspx.

Hledik, R. (2014). "Rediscovering Residential Demand Charges." The Electricity Journal (27:7), 2014; pp. 82-96. Accessed December 19, 2014: http://ac.els-cdn.com/S1040619 01400150X/1s2.0-S104061901400150X-main.pdf? tid=12d2a4f8-04c9-11e5-986a00000aacb362\&acdnat $=1432769915 \quad 5 \mathrm{c} 8 \mathrm{fd} 3 \mathrm{a} 85 \mathrm{e} 05 \mathrm{cad} 5 \mathrm{~d} 5 \mathrm{bfa} 3 \mathrm{f} 91 \mathrm{~d} 0 \mathrm{bc} 610$.

Kansas City Power \& Light Company. 2014. Minimum Filing Requirements for Utility Company General Rate Increases.

Kennerly, Jim, Kathryn Wright, Chad Laurent, Wilson Rickerson, Autumn Proudlove. (2014). Rethinking Standby \& Fixed Cost Charges: Regulatory \& Rate Design Pathways to Deeper Solar PV Cost Reduction. Solar Energy Industries Association: Report. August 2014. http://www.seia.org/sites/default/files/resources/ Rethinking-Standby-and-Fixed-CostCharges_V2.pdf (accessed 11/14/2014).

Kind, P. (January 2013). "Disruptive Challenges: Financial Implications and Strategic Responses to a Changing Retail Electric Business." Prepared for Edison Electric Institute. Washington, DC: 26 pp. Accessed April 14, 2015: http://www.eei.org/ourissues/finance/documents/disruptive challenges.pdf.

Lazar, J (2014a). Rate Design Where Advanced Metering Infrastructure Has Not Been Fully Deployed. The Regulatory Assistance Project.

http://www.raponline.org/document/download/id/6516

Lazar, Jim. (2014b). Electric Utility Residential Customer Charges and Minimum Bills: Alternative Approaches for Recovering Basic Distribution Cost. The Regulatory Assistance Project, November, 2014. http://www.raponline.org/document/download/id/7361.

Linvill, C.; Shenot, J.; Lazar, J. (2013). Designing Distributed Generation Tariffs Well: Fair Compensation in a Time of Transition. Montpelier, VT: Regulatory Assistance Project. Accessed January 22, 2015: http://www.raponline.org/document/download/id/6898.

Long Island Power Authority. (2009). Understanding Electric Demand. FC 11230. July, 2009. Accessed July 28, 2015: http://www.lipower.org/pdfs/company/pubs/brochures/ electricdemand.pdf.

NCCETS and Meister Consultants Group. (2015). The 50 States of Solar: A Quarterly Look at America's Fast-Evolving Distributed Solar Policy Conversation, Q1 2015. 
Newcomb, J.; Lacy, V.; Hansen, L.; Bell, M. (2013). “Distributed Energy Resources: Policy Implications of Decentralization." The Electricity Journal (26:8), 2013; pp. 67-87. Accessed January 25, 2015: http://www.sciencedirect.com/science/article/pii/S104061901300208X\#.

Ong, S.; Denholm, P.; Doris, E. (2010). The Impacts of Commercial Electric Utility Rate Structure Elements on the Economics of Photovoltaic Systems. NREL/TP-6A2-46782. Golden, CO: National Renewable Energy Laboratory. Accessed April 11, 2015: http://www.nrel.gov/docs/fy10osti/46782.pdf.

Ong, S.; Campbell, C.; Clark, N. (2012a). Impacts of Regional Electricity Prices and Building Type on the Economics of Commercial Photovoltaic Systems. NREL/TP-6A20-56461. Golden, CO: National Renewable Energy Laboratory. Accessed April 11, 2015; http://www.nrel.gov/docs/fy13osti/56461.pdf.

Ong, S; Denholm, P.; Clark, N. (2012b). "Grid Parity for Residential Photovoltaics in the United States: Key Drivers and Sensitivities.” Preprint. NREL Report No. CP-6A20-54527. Golden, CO: National Renewable Energy Laboratory.

Ong, S.; Clark, N.; Denholm, P.; Margolis, R. (2013). Breakeven Prices for Photovoltaics on Supermarkets in the United States. NREL/TP-6A20-57276. Golden, CO: National Renewable Energy Laboratory. Accessed February 9, 2015: http://www.nrel.gov/docs/fy13osti/57276.pdf.

OpenEI. (2015). "Commercial and Residential Hourly Load Profiles for all TMY3 Locations in the United States | OpenEI." Open Energy Information (OpenEI). Accessed March 7, 2015 : http://en.openei.org/doe-opendata/dataset/commercial-and-residential-hourly-load-profiles-forall-tmy3-locations-in-the-united-states.

Open PV. (2015). “The Open PV Project: Solar Search.” Open PV. Accessed March 27, 2015: https://openpv.nrel.gov/search.

Pyper, J. (2014). "Wisconsin Regulators Vote to Raise Fixed Charges, Add Solar Fees."Greentech Media Accessed April 9, 2015: http://www.greentechmedia.com/articles/read /wisconsin-regulators-vote-to-raise-fixed-charges-and-add-solar-fees.

Raskin, D. (2013). “The Regulatory Challenge of Distributed Generation.” Harvard Business Law Review Online (4); pp. 38-51. Accessed April 12, 2015: http://www.hblr.org/wpcontent/uploads/2013/12/Raskin_The-Regulatory-Challenge-Of-Distributed-Generation.pdf.

Snook, Leland (2015) APS Residential Demand Rates. Presentation at EUCI Demand Charges Summit. May 14, 2015. Denver, CO

Stanton, Tom (2013). State and Utility Solar Energy Programs: Recommended Approaches for Growing Markets. Silver Spring, MD: National Regulatory Research Institute, 2013, p. 24.

Sterling, J.; McLaren, J.; Taylor, M.; Cory, K. (2013). Treatment of Solar Generation in Electric Utility Resource Planning. NREL/TP-6A20-60047. Golden, CO: National Renewable Energy Laboratory. Accessed June 1, 2015: http://www.nrel.gov/docs/fy14osti/60047.pdf. 
Stone, Paige (2015) Residential Demand Rate Development. Presentation at EUCI Demand Charges Summit. May 14, 2015. Denver, CO

U.S. Energy Information Administration. (2015). "Electric power sales, revenue and energy efficiency Form EIA-861 detailed data files.” U.S. Energy Information Administration. Accessed April 23, 2015: http://www.eia.gov/ electricity/data/eia861/.

Utility Rate Database (URDB). (2015). http://en.openei.org/wiki/Utility_Rate Database, Accessed 7/23/2015.

Wilcox, S.; Marion, W. (2008). Users Manual for TMY3 Data Sets. NREL/TP-581-43156. Golden, CO: National Renewable Energy Laboratory. Accessed February 10, 2015: http://www.nrel.gov/docs/fy08osti/43156.pdf. 


\section{Appendix A}

\begin{tabular}{|c|c|c|c|}
\hline LOCATION & $\begin{array}{c}\text { "LOW" } \\
\text { Annual Residential } \\
\text { Electricity Consumption } \\
\text { (kWh) }\end{array}$ & $\begin{array}{c}\text { "BASE CASE" } \\
\text { Annual Residential } \\
\text { Electricity Consumption } \\
\text { (kWh) }\end{array}$ & $\begin{array}{c}\text { "HIGH" } \\
\text { Annual Residential } \\
\text { Electricity Consumption } \\
\text { (kWh) }\end{array}$ \\
\hline California-PG\&E & 3,908 & 7,563 & 10,177 \\
\hline Oregon-PGECo & 3,999 & 7,753 & 10,475 \\
\hline California-LADWP & 4,063 & 7,930 & 11,740 \\
\hline Massa chusetts-NSTAR & 4,382 & 9,011 & 13,836 \\
\hline Colorado-PSCo & 4,320 & 9,020 & 13,741 \\
\hline Nevada-SPPCo & 4,361 & 9,034 & 14,109 \\
\hline Minnesota-NSPCo & 4,469 & 9,235 & 14,417 \\
\hline New Jersey-JCP\&L & 6,662 & 12,223 & 17,688 \\
\hline Virginia-VEPCo & 6,927 & 12,825 & 19,164 \\
\hline North Carolina-Duke & 6,962 & 12,880 & 19,280 \\
\hline Arizona-APS & 6,020 & 12,918 & 21,520 \\
\hline Georgia-GeorgiaPower & 7,035 & 13,039 & 19,676 \\
\hline Florida-FPL & 7,587 & 14,690 & 25,299 \\
\hline Texas-AustinEnergy & 7,129 & 14,796 & 26,964 \\
\hline AVERAGE & 5,559 & 10,923 & 17,006 \\
\hline
\end{tabular}




\section{Appendix B}

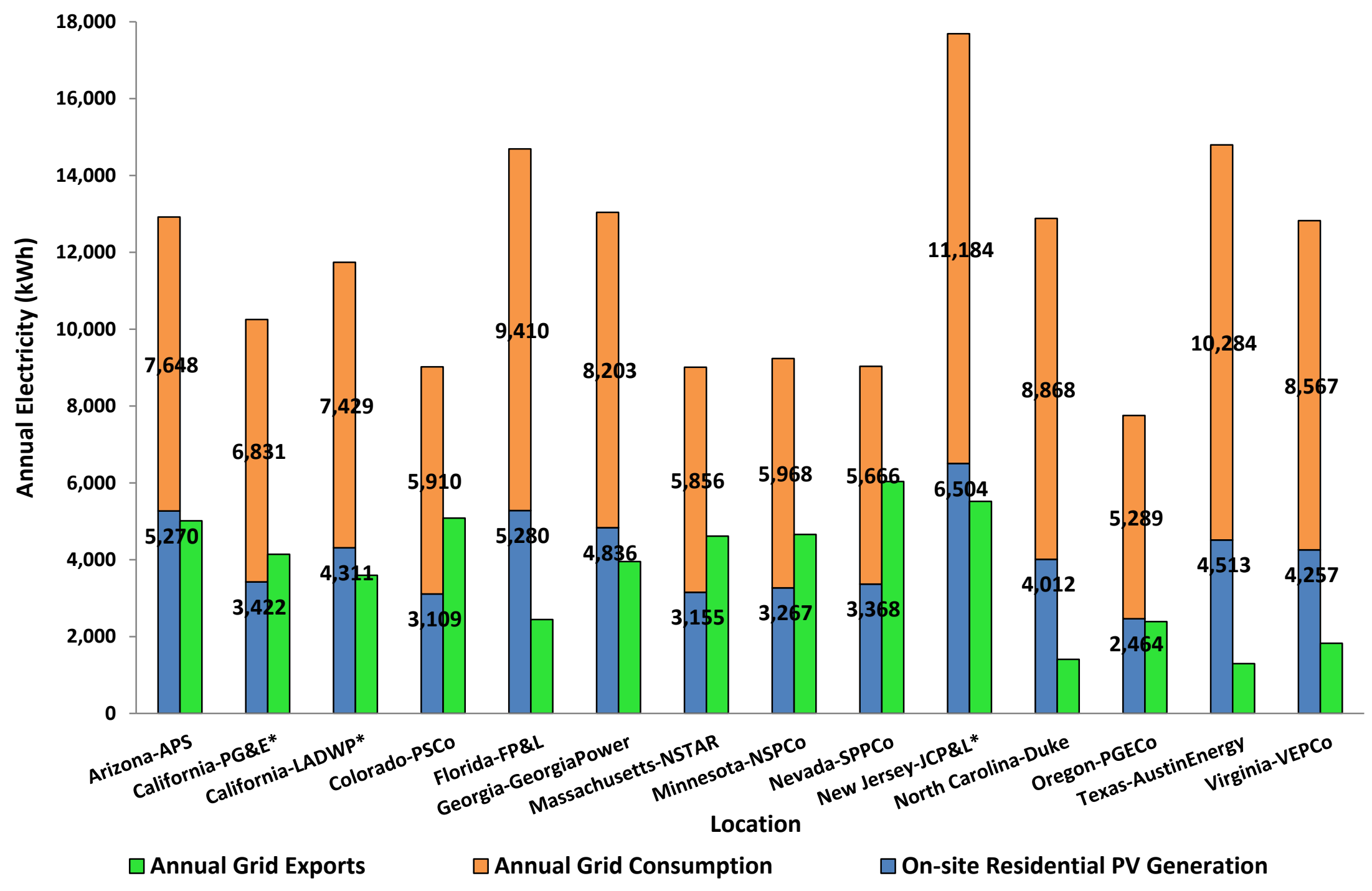




\section{Appendix C}

\section{Utility Rate Structure Options}

Standard Rate - A standard default residential rate ('standard rate') is a set fee, based on the number of kWh a customer consumes, which is assessed through an energy charge, and traditionally makes up the largest percentage of a residential electric bill. There may be a single energy charge for all hours of the day and year (flat rate), however the energy charge often varies seasonally. It may also vary according to the time of day (time-of-use rate).

Increased fixed Charge- A fixed charge is a single service-based charge each billing period, in addition to the energy charge, which does not vary based on customer energy usage and is primarily intended to recover utility administrative and billing costs. A net-metered solar customer with net zero consumption from the grid still pays the fixed charge portion of their electricity bill. As such, increasing the fixed cost portion of the electricity bill has been a common proposal in response to concerns about utility revenue loss associated with distributed solar, as it is easy to implement and convey to customers. Criticisms of this method include the fact that higher fixed charges discourage energy efficiency, reduce potential cost savings from distributed generation, and could burden low-income customers.

Minimum Bill - A minimum bill sets a lower limit that a customer will pay each billing period. Customers that reduce their monthly energy charges from the utility by any means possible, including through the use of distributed energy systems that provide for the majority (or more) of their electricity needs, could trigger the minimum bill. Depending on the level at which the minimum bill is set, this option would not affect distributed generators with smaller systems or at least many low-income customers.

Demand-based Rate- A demand-based rate structure is similar to a standard rate in that it includes an additional component called a demand charge. This component of the bill is based on the maximum $\mathrm{kW}$ used over a specified time interval. The demand charge is based on some measure of the extent to which the customer requires the utility to have capacity available to meet the customer's peak demand. In some instances, a demand ratchet is implemented which states that the minimum billed demand is a percentage of the maximum historical peak demand during a specified period (Long Island Power Authority 2009). The intervals used are typically 15 minutes, 30 minutes or an hour. At the end of a billing period, the time interval in which the maximum capacity of electricity was used (at any time interval) is determined. The demand is averaged over that interval and the appropriate demand charge rate is multiplied by that figure to arrive at the demand charge component of the bill. A demand-based rate structure typically has a lower energy charge component than the typical standard rate. 